\title{
Genomics Associated Interventions for Heat Stress Tolerance in Cool Season Adapted Grain Legumes
}

\author{
Jitendra Kumar ${ }^{1, *}$, Reyazul Rouf Mir ${ }^{2, *}$, Safoora Shafi ${ }^{2}$, Debjyoti Sen Gupta ${ }^{1}$, Ivica Djalovic ${ }^{3, *}$, \\ Jegor Miladinovic ${ }^{3}$, Rahul Kumar ${ }^{4}$, Sachin Kumar ${ }^{4} \mathbb{D}$ and Rajeev Kumar ${ }^{5}$
}

Citation: Kumar, J.; Mir, R.R.; Shafi, S.; Sen Gupta, D.; Djalovic, I.;

Miladinovic, J.; Kumar, R.; Kumar, S.; Kumar, R. Genomics Associated Interventions for Heat Stress Tolerance in Cool Season Adapted Grain Legumes. Int. J. Mol. Sci. 2022, 23,399. https://doi.org/10.3390/ ijms23010399

Academic Editors: Sergey Shabala, Om Parkash Dhankher and P.V. Vara Prasad

Received: 5 December 2021

Accepted: 27 December 2021

Published: 30 December 2021

Publisher's Note: MDPI stays neutral with regard to jurisdictional claims in published maps and institutional affiliations.

Copyright: (c) 2021 by the authors. Licensee MDPI, Basel, Switzerland. This article is an open access article distributed under the terms and conditions of the Creative Commons Attribution (CC BY) license (https:/ / creativecommons.org/licenses/by/ $4.0 /)$.
1 Division of Crop Improvement, ICAR-Indian Institute of Pulses Research, Kanpur 208024, India; debgpb@gmail.com

2 Division of Genetics and Plant Breeding, Faculty of Agriculture (FoA), Wadura Campus, SKUAST-Kashmir, Sopore 193201, India; safoorashafi999@gmail.com

3 Institute of Field and Vegetable Crops, National Institute of the Republic of Serbia, Maxim Gorki 30, 21000 Novi Sad, Serbia; jegor.miladinovic@ifvcns.ns.ac.rs

4 Department of Genetics and Plant Breeding, Ch Charan Singh University, Meerut 250005, India; rkdsum@gmail.com (R.K.); sachinkpsingh@gmail.com (S.K.)

5 Faculty of Agriculture, C.S.S.S.P.G College, Meerut 250106, India; rnain1972@gmail.com

* Correspondence: jitendra.kumar@icar.gov.in (J.K.); rrmir@skuastkashmir.ac.in (R.R.M.); ivica.djalovic@ifvcns.ns.ac.rs (I.D.)

\begin{abstract}
Cool season grain legumes occupy an important place among the agricultural crops and essentially provide multiple benefits including food supply, nutrition security, soil fertility improvement and revenue for farmers all over the world. However, owing to climate change, the average temperature is steadily rising, which negatively affects crop performance and limits their yield. Terminal heat stress that mainly occurred during grain development phases severely harms grain quality and weight in legumes adapted to the cool season, such as lentils, faba beans, chickpeas, field peas, etc. Although, traditional breeding approaches with advanced screening procedures have been employed to identify heat tolerant legume cultivars. Unfortunately, traditional breeding pipelines alone are no longer enough to meet global demands. Genomics-assisted interventions including new-generation sequencing technologies and genotyping platforms have facilitated the development of high-resolution molecular maps, QTL/gene discovery and marker-assisted introgression, thereby improving the efficiency in legumes breeding to develop stress-resilient varieties. Based on the current scenario, we attempted to review the intervention of genomics to decipher different components of tolerance to heat stress and future possibilities of using newly developed genomics-based interventions in cool season adapted grain legumes.
\end{abstract}

Keywords: climate change; high temperature; epigenetics; genome editing; nanoparticles; candidate genes; mRNA; signalling pathways

\section{Introduction}

Cool season grain legumes are rich in proteins, vitamins, and minerals such as iron, zinc, and folate. Hence, their intake in daily diet provides solution of overcoming the problem of malnutrition and mineral deficiencies among the poor people of developing countries who cannot afford costly animal protein-based diets. Moreover, use of grain legumes provides a remedy for several chronic diseases like diabetes, obesity, and cardiovascular problems [1]. Therefore, health conscious people now prefer use of plant-based protein in their diets even in developing countries over animal-based proteins [2]. This is resulted in increasing the demand of grain legumes day by day. However, several biotic (i.e., wilt, rust, blight diseases) and abiotic (i.e., heat, drought, salinity, acidity and water logging) stresses significantly affect the yield potential of current cultivars of food legumes [2,3]. Among abiotic stresses, heat stress is increasingly becoming a serious problem for the production of cool season grain legumes due to climate changes [4]. Heat 
shock and moderate heat stress are two types of heat stress. First is occurred due to lethal temperatures for a short period of time, while later one is commenced when temperatures arise above the optimum level for a long period of time [5]. Moderate heat stress generally affects the growth and development of cool season legumes. In India, a large shift in area of grain legumes from cooler, long season environments to warm, short season environments has been made in the past years due to changes in the environmental conditions. For example, the area under chickpea cultivation has been shifted from northern to southern India. Many other countries also could experience unprecedented heat stress due to global changes in climate. Cool season grain legumes including chickpea (Cicer arietinum L.), lentil (Lens culinaris Medik.) and faba bean (Vicia faba L.) have yield losses if day temperatures are increased from critical day temperatures of $35^{\circ} \mathrm{C}$. Heat stress during flowering reduced yield in pea (Pisum satioum L.) [6]. In the common bean (Phaseolus spp.), high night temperature $\left(>20^{\circ} \mathrm{C}\right)$ causes yield losses. In India, it is grown as a cool season crop during winter season despite its being a warm season crop.

Heat stress in a complex trait and a network of genes, which controls the physiological and agronomic traits, is involved in tolerance to heat stress. For example, in common bean, enhanced leaf cooling identified as a pathway for heat stress tolerance [7]. Thus, conventional breeding approaches could not be very successful in developing the heattolerant cultivars in food legumes due to complex inheritance, except a few cases in chickpea and faba bean [8-10] and other warm season crops like cowpea [11]. However, heat-tolerant genotypes have been identified in a number of cool season grain legumes for further utilization in conventional breeding for developing heat-tolerant cultivars [12-15]. Efforts have been made to improve the heat tolerance through conventional breeding approaches, and screening methodologies have been developed to identify heat tolerant cultivars $[15,16]$. In recent years, genomics has emerged as a way to decipher the genetics underlying complex traits imparting heat stress tolerance in food legumes and published several reviews focussed on different aspects of heat stress including seed setting [17], functional mechanism [18], heat stress during reproductive and grain-filling phases [19], functional genomics [20], physiological and molecular approach [21], and breeding, genetics and genomics [2]. In the recent past years, new knowledge have been generated in the area of genomics for tackling heat stress tolerance in cool season grain legumes, which were not covered in previously published review articles. Therefore, in this review, we discussed current and future genomics inventions for heat stress tolerance in the context of cool season grain legumes.

\section{Advances in Screening Techniques for Heat Tolerance}

Heat-tolerant genotype has minimum yield losses, when temperature goes beyond the threshold temperature. In cool season grain legumes, critical threshold temperature is varied from 28 to $35^{\circ} \mathrm{C}$ [19]. Temperature above $28^{\circ} \mathrm{C}$ during reproductive period causes sensitivity of pea crop [22]. While in lentil and chickpea, temperature greater than $35^{\circ} \mathrm{C}$ during flowering and podding resulted in poor grain yield [15]. Significant yield losses have been observed in faba bean under daily temperatures $>25^{\circ} \mathrm{C}[23,24]$, and stops flowering and produces a few extra leaf-bearing nodes at $30^{\circ} \mathrm{C}$ [25]. The critical temperature for heat tolerance seems to be higher in chickpea than faba bean, lentil, and field pea, and the reverse is true for cold tolerance [26]. Thus, this crop shows high sensitivity to heat stress. Heat stress affects several phonological, biochemical and physiological traits such as limited growth rate, membrane instability, photosynthesis, reproductive development, and reduced net assimilation rate $[17,24-30]$. Heat stress sensitivity has been observed more in cool season grain legumes compared to warm season food legumes [8].

Different approaches have been used to differentiate the heat tolerant and sensitive genotypes by screening a number of genotypes at the temperature higher than the threshold level in cool season grain legumes (Figure 1). 


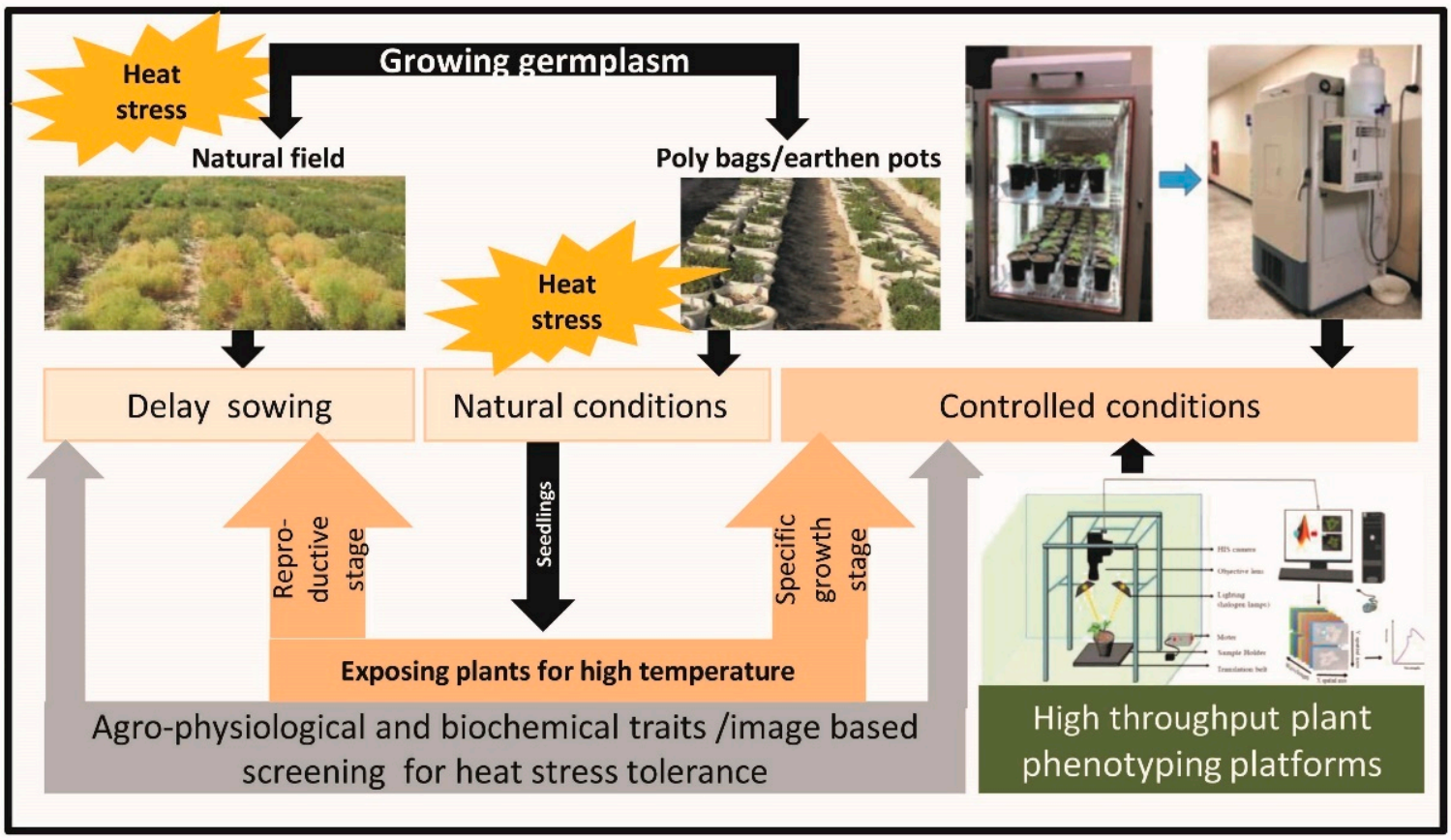

Figure 1. An overview of screening methodologies used for identification of differentiating heat tolerant and sensitive genotypes in cool season grain legumes (modified from [31]).

Delay sowing of genotypes under natural conditions in the field has been used as one of the approaches for this purpose. It is planned in this way that reproductive period could coincide with high temperature (i.e., greater than the threshold temperature). It is widely used in several cool season grain legumes including chickpea and lentil [15]. However, in another study, lentil genotypes were grown in earthen pots following delay sowing in order to ensure heat stress $\left(>30 / 20^{\circ} \mathrm{C}\right.$; average max./min. temperatures) during seed filling [28]. Advancement in screening technologies resulted in development of several approaches for screening heat stress tolerance in crop plants including cool season grain legumes. These approaches used both natural and controlled conditions to grow plants under heat stress. For this, plants initially were grown under field conditions in earthen pots or poly bags and after that they were transferred in controlled conditions for exposing them to high temperature. Another way used for screening heat stress tolerance is to grow plants of different genotypes in pots under controlled conditions for their whole life cycle and then higher temperature is given at desired stage of plants. In chickpea, polybags have been used to grow different genotypes and 14-days-old seedlings were subsequently exposed to elevated temperature by creating polythene structure [32]. As we know, flowering time and duration are important traits for managing stress through escape. Therefore, efforts have been made to develop the image-based techniques for high-throughput phenotyping of flowering intensity in cool season grain legumes [33]. This study used multiple imaging sensors, image resolution, and image processing techniques in monitoring flowering intensity in chickpea and pea and found strong correlation of image data with visual rating scores in pea $(r=0.72)$. This study demonstrated possibility of using imaging for phenotyping of flowering in crop plants [33]. Besides high-throughput phenotyping of individual plants, advances in phenomics resulted in development of smartphone app platform for field phenotyping at organ level using images and pictures [34]. It is very comfortable to take 2D pictures of targeted organ like leaf angel and leaf length through this. Multi-view stereo (MVS) approach is another way of organ phenotyping at a low cost [35]. Further automation and robotics, new sensors, and imaging technologies (and software) are emerging opportunities for developing high-throughput plant phenotyping platforms (HTPPs) for screening high temperature tolerant genotypes in coming years [36]. Further, technological advances in digital cameras, infrared thermal imagers, light detection and ranging (LIDAR), 
multispectral cameras, and hyperspectral sensors are becoming helpful in developing of ground-based platforms and aerial-based platforms for phenotyping under field environments [37]. For example, in sorghum, the tractor-based proximal crop-sensing platform, and UAV (unmanned aerial vehicle)-based platform helped to phenotype complex traits like growth and radiation use efficiency (RUE) in sorghum [38].

\section{Genomics Interventions}

In cool season grain legumes, significant progress has been made to enrich genomic resources (Table 1), which helped to develop the different types of molecular markers including SSRs, diversity arrays technology (DArT) markers, single nucleotide polymorphism (SNP) markers, different SNP platforms, micro-array based markers, NGS-based markers, genotyping by sequencing (GBS), InDel markers etc. [39-43] and other genomicbased tools and techniques. Advances in genomics have led to intervention in its use for enhancing the knowledge on heat-stress tolerance through the following ways (Figure 2).

Table 1. Genomic resources in cool season grain legumes.

\begin{tabular}{|c|c|c|c|c|c|}
\hline Crop & Reads/EST & Unigenes/Transcript & SSR & SNPs & References \\
\hline \multirow{8}{*}{ Chickpea } & - & 160,883 & & 1022 & [44] \\
\hline & - & 2619 & 81,845 & 76,084 & [45] \\
\hline & - & 53,409 & 4816 & & [46] \\
\hline & - & 34,760 & 4111 & 495 & [47] \\
\hline & - & 103,215 & 26,252 & 26,082 & [48] \\
\hline & - & - & - & 14,454 & [49] \\
\hline & - & 37,265 & 4072 & 36,446 & [50] \\
\hline & - & 43,389 & 5409 & 39,940 & [51] \\
\hline \multirow{8}{*}{ Lentil } & $1,380,000$ & 25,592 & - & - & [52] \\
\hline & $1,030,000$ & 27,921 & - & - & [53] \\
\hline & $119,855,798$ & 20,009 & - & - & [54] \\
\hline & $111,105,153$ & 97,528 & - & - & [55] \\
\hline & $58,621,121$ & 77,346 & - & - & [56] \\
\hline & $46,700,000$ & - & - & - & [57] \\
\hline & $26,165,023$ & 96,824 & - & - & {$[2,58]$} \\
\hline & - & - & - & - & \\
\hline \multirow[t]{20}{*}{ Pea } & 1005.1 million & & - & 16,877 & [59] \\
\hline & - & - & - & 10,739 & [60] \\
\hline & & - & - & 36,188 & [61] \\
\hline & 18,552 & 10,086 & 586 & - & [62] \\
\hline & - & - & - & 520 & [63] \\
\hline & - & - & - & 340 & [64] \\
\hline & - & - & - & 956 & [61] \\
\hline & $3,042,418$ & & - & 35,455 & [65] \\
\hline & & & - & 8822 & [66] \\
\hline & $2,209,735$ & 195,661 & - & & [67] \\
\hline & 40,903 & 10,506 & $\begin{array}{l}- \\
-\end{array}$ & & [68] \\
\hline & & & - & 248,617 & [69] \\
\hline & 432 million & 27,145 & - & - & [70] \\
\hline & one billion reads & 52,477 & - & - & [71] \\
\hline & $69,706,469$ & 48,628 & - & - & [72] \\
\hline & $\sim 55$ million & 81,774 & - & - & [73] \\
\hline & 88 million & 7946 & - & - & [74] \\
\hline & - & 8899 & 3275 & - & [75] \\
\hline & - & 10,800 & 2395 & - & [76] \\
\hline & 720,324 & 70,682 & 2397 & - & [77] \\
\hline
\end{tabular}


Table 1. Cont.

\begin{tabular}{|c|c|c|c|c|c|}
\hline Crop & Reads/EST & Unigenes/Transcript & SSR & SNPs & References \\
\hline \multirow[t]{4}{*}{ Grass pea } & 493,364 & & 651,827 & - & [78] \\
\hline & 570 million & 27,431 & 3204 & 146,406 & [79] \\
\hline & $\begin{array}{c}46,994,629+ \\
72,566,465\end{array}$ & 134,914 & 200 & 4892 & [80] \\
\hline & 399,648 & 14,386 & - & - & [81] \\
\hline \multirow{7}{*}{$\begin{array}{l}\text { Faba } \\
\text { bean }\end{array}$} & - & & - & 14,552 & [82] \\
\hline & - & 37,378 & 9071 & - & [83] \\
\hline & - & & $\begin{array}{c}25,502+ \\
12,319\end{array}$ & - & [84] \\
\hline & $1,247,881$ & 343,325 & - & $560-2144$ & [85] \\
\hline & 87,269 & - & - & 39,060 & [86] \\
\hline & - & - & 28,503 & - & [87] \\
\hline & 304,680 & 60,440 & 802 & - & [77] \\
\hline \multirow[t]{17}{*}{$\begin{array}{l}\text { Common } \\
\text { bean }\end{array}$} & & - & 629 & - & [88] \\
\hline & 3123 & - & 184 & - & [89] \\
\hline & & - & - & 7015 & [90] \\
\hline & 418 million & - & - & 346,819 & [91] \\
\hline & - & - & - & 19,204 & [92] \\
\hline & - & - & - & 17,190 & [93] \\
\hline & - & - & - & 43,018 & [94] \\
\hline & - & - & - & 12,697 & [95] \\
\hline & - & - & - & 230 & [96] \\
\hline & 21,026 & 7969 & - & - & [97] \\
\hline & - & 3126 & - & - & [98] \\
\hline & - & & - & 1800 & [99] \\
\hline & 7079 & 4219 & - & - & [100] \\
\hline & 37,919 & 10,581 & - & - & [101] \\
\hline & 9583 & - & 4764 & - & [102] \\
\hline & - & 59,295 & - & - & [103] \\
\hline & 900,000 & 30,491 & - & - & [104] \\
\hline
\end{tabular}

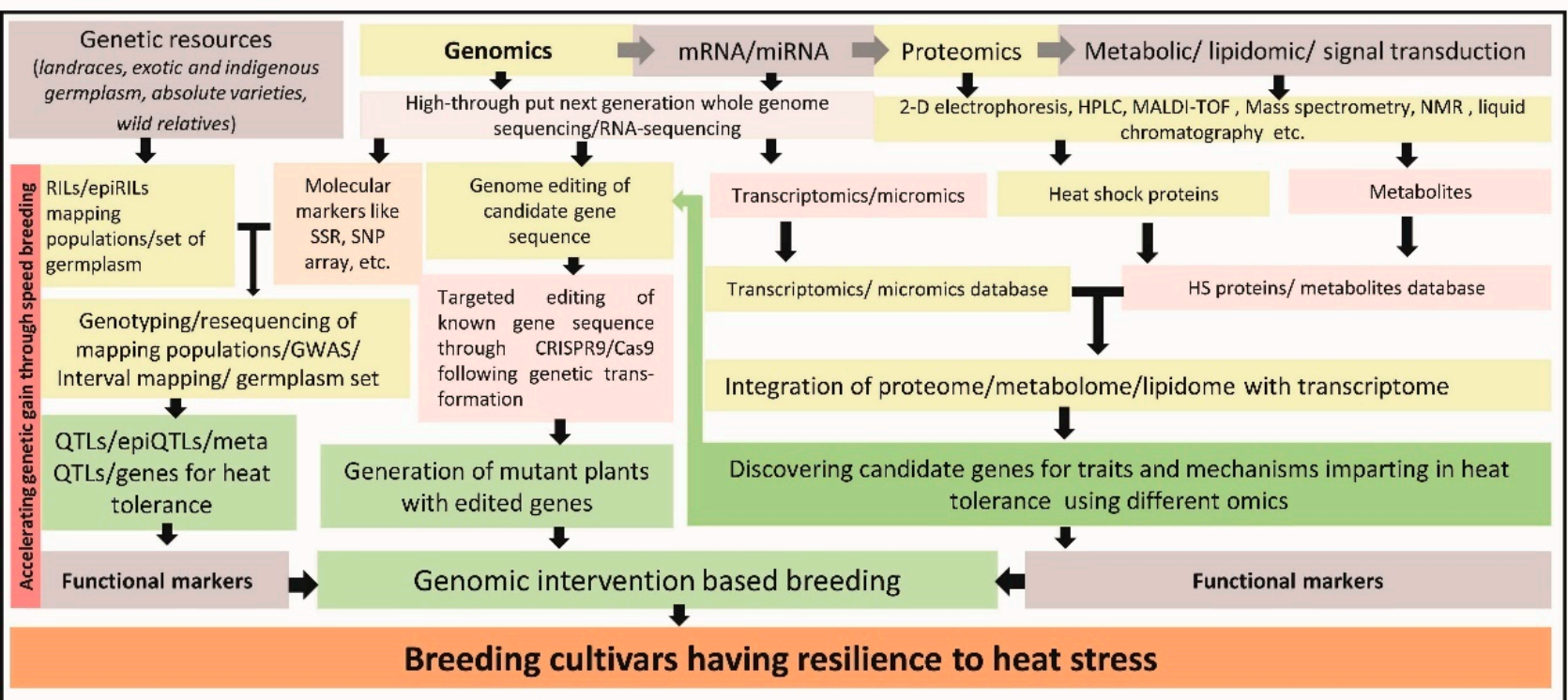

Figure 2. An overview of genomic interventions based breeding strategies for heat stress tolerance in cool season legumes. 


\subsection{QTL/Gene Mapped for Traits Imparting Heat Stress}

Heat stress is a complex trait and many genes control those complex traits that impart heat-stress tolerance. Developments in genomics have made it feasible to dissect genetic architecture of underlying such complex traits through QTL/gene mapping. Molecular markers help to tag the genomic regions (i.e., quantitative trait loci; QTLs) controlling the phenotype of a complex trait, which are distributed throughout the genome.

Each QTL is comprised of many genes, which are investigated as potential candidate genes for a trait under study. Mapping populations derived from two parents (i.e., biparental QTL mapping) and multi-parents/association panel (i.e., association mapping) are usually used to map the QTLs/genes controlling a trait of interest $[105,106]$. However, markers linked a QTL controlling complex traits have not been used in marker assisted breeding program due to poor markers density within QTL regions. However, next-generation sequencing-based approaches especially genotyping by sequencing (GBS) have provided a large number of evenly distributed SNP and gene SSR markers over genome $[107,108]$. This led to development of high resolution linkage maps in cool season grain legume crops [109-112], and are used to map several traits including traits imparting in heat tolerance (Table 2).

Table 2. QTLs mapping for traits associated with heat stress tolerance in cool season grain legumes.

\begin{tabular}{|c|c|c|c|c|c|}
\hline Crop & Traits & $\begin{array}{l}\text { QTL Name/No. of } \\
\text { MTAs }\end{array}$ & $\begin{array}{l}\text { Population } \\
\text { Size }\end{array}$ & $\begin{array}{l}\text { PVE } \\
(\%)\end{array}$ & Reference \\
\hline \multirow[t]{5}{*}{ Chickpea } & filled pods/plot & qfpod02_5 & 292 & 12.03 & [113] \\
\hline & total number of seeds/plot & qts02_5 & 292 & 10.00 & [113] \\
\hline & grain yield per plot & Qgy02_5 & 292 & 16.56 & [113] \\
\hline & $\%$ pod setting & q\%podset06_5 & 292 & 13.30 & {$[39,113]$} \\
\hline & chlorophyll content & - & 206 & 17.2 & {$[114]$} \\
\hline \multirow[t]{2}{*}{ Lentil } & seedling survival & $q H t \_s s$ & 142 & 12.1 & [115] \\
\hline & pod set & $q H t \_p s$ & 147 & 9.23 & [115] \\
\hline \multirow[t]{6}{*}{ Field pea } & chlorophyll concentration & 6 & 135 & $7-13$ & [116] \\
\hline & photochemical reflectance index & 2 & 135 & 9 & [116] \\
\hline & canopy temperature & 2 & 135 & 6 & [116] \\
\hline & reproductive stem length & 6 & 135 & $4-6$ & [116] \\
\hline & internode length & 6 & 135 & $5-7$ & [116] \\
\hline & pod number & 9 & 135 & $7-10$ & [116] \\
\hline
\end{tabular}

In chickpea, a linkage map spanning $529.11 \mathrm{cM}$ and comprising 271 genotyping by sequencing (GBS) based single nucleotide polymorphism (SNP) markers identified major QTL for number of filled pods per plot, total number of seeds per plot, grain yield per plot and \% pod setting under heat stress [113]. In some cases, candidate genes controlling associated quantitative traits have been identified [117]. Moreover, genomewide association studies (GWAS) allow narrowing down the candidate regions to explore specific haplotypes in natural populations and even wild species $[118,119]$. In chickpea, a recent GWAS was conducted in a panel of 300 accessions to investigate the marker-trait association for heat tolerance [120]. In pea, genome-wide association (GWA) analysis with 16,877 known high-quality SNPs identified association of genomic regions with chlorophyll concentration (6 QTLs), with photochemical reflectance index and canopy temperature (2 QTLs); reproductive stem length (7 QTLs), internode length (6 QTLs) and pod number (9 QTLs) and also identified 48 candidate genes responsible for these traits under heat stress [116]. QTLs for heat tolerance have also been mapped using GWAS in cereals like wheat (Triticum aestivum L.) [121-126] and jowar or sorghum (Sorghum bicolor L.) [127]. Several QTLs for heat tolerance at flowering stage have been identified and used in breeding program for developing heat tolerant cultivars of rice (Oryza sativa L.), [128-130]. In maize (Zea mays L.), QTL hot spots for grain yield under heat stress have been identified [131].

Among food legumes, two dominant genes for heat stress tolerance [132] and QTLs for pod set number per peduncle under HS have been identified in cowpea (Vigna unguiculata L.) $[133,134]$. Further comparative genomic analysis identified HSPs and HSFs in these QTL 
regions in soybean (Glycine max L.) [3]. In azuki bean [V. angularis var. angularis (Willd.) Ohwi and Ohashi]], QTL mapping was done for pollen viability trait under heat stress and identified two QTLs (i.e., HQTL1 and HQTL2 [135,136]. In pea, genetic bases of several traits including agronomic and seed quality traits $[59,64]$, disease resistance $[137,138]$, seed mineral concentrations [139], seed lipid content [140], salinity tolerance [141], and frost tolerance [142], have been uncovered through molecular mapping. Despite its importance, only limited studies have been carried out to identify genomic regions associated with stress tolerance in pea [143]. Therefore, more efforts are required to use the available genomic resources for mapping/tagging the genes/QTLs controlling the traits imparting in heat stress tolerance in cool season grain legumes.

\subsection{Transcriptomics, Transcription Factors and Candidate Genes}

Next generation sequencing (NGS) and RNA sequencing have led to unraveling and understanding many heat-tolerant candidate genes in different crops species [144-147]. Transcriptome analyses have been conducted in many legumes including cool season grain legumes for heat tolerance. For instance, in cowpea, the expression of various thermotolerant genes has been analyzed using cDNA-AFLP [148]. Efforts have been made to understand the genetic mechanism underlying heat shock factors (HSF) which play a vital role for survival under heat stress in many crop species. HSF-ESTs (expressed sequence tags), have been identified in Lotus japonicas (19), Medicago truncatula (21) and soybean (25) [149]. Transcript expression of VfHsp17.9CII gene in faba bean showed its increased accumulation and made 620-fold changes under high temperature [150]. Furthermore, in soybean HSP genes (HSP 20, GmHsfA1) and their role in thermo-tolerance have been evaluated [151-153]. Under different stress conditions, transcription factors (TF) are pivotal in modulating cellular responses and there by activating the transcription of target gene. These heat stress transcription factors (Hsfs) mediate activation of heat-responsive genes and chemical stressors through the signal transduction chain $[154,155]$. WRKY TFs have been identified as a major family of transcriptional regulators in other plant species, which form an integral part of cell signaling pathways and influence the stress tolerance [156]. Heat-stress elements (HSE: 50-AGAAnnTTCT-30) or palindromic binding motifs of promoters of heat stress (hs) genes are found conserved in eukaryotes [157]. Arabidopsis thaliana (HsfA2) is a typical representative of plant Hsfs having a modular structure [158]. Sequence comparisons has indicated that the combination of a C-terminal activator motif (AHA motif) with the consensus sequence $F W x x(F / L)(F / I / L)$ to an adjacent nuclear export signal (NES) represent a signature domain for many plant class A Hsfs; this domain has enabled the identification of more than 90 unassigned new plant Hsfs and Hsf fragments in EST databases $[159,160]$. APETALA2/ethylene response factor (AP2/ERF) superfamily and heat-shock protein 90 (HSP90) family are another important stress responsive gene family [161]. These families not only regulate responses against various biotic and abiotic stresses in plants but also play an important role in various developmental processes.

In recent years, genome sequence availability of many cool season grain legumes like chickpea [45], lentil [162], and pea [163] has greatly helped in understanding the mechanism underlying stress tolerance. In chickpea, DNAJ, HSP 70 and HSP 91 genes have been reported by using Illumina/Solexa sequencing [164]. In addition, complete transcriptome analysis of heat-responsive genes in heat-sensitive genotypes (ICC 5912, ICC 4567, and ICC 10685) and heat-tolerant genotypes (ICC 15614, ICC 1356, and ICC 92944) has been also reported in chickpea [165]. Major gene families for heat stress like AP2/ERF gene family has also been reported in an earlier study [166]. One AP2 domain and three ERFs clustered with AP2 sequences have also been identified in chickpea [166]. Deokar et al. [167], also identified 16 AP2 and 120 putative ERF TFs in chickpea. This study strictly identified and characterized the AP2s through the presence of two AP2 domains [167]. Furthermore, transcription factors (TFs) for heat tolerance have been reported in chickpea $[166,168]$. Car-WRKY has been reported to be a multi-stress responsive transcription factor and plays a crucial role in stress signal transduction pathways [169]. Genome-wide analysis 
of a WRKY TF gene model has revealed the presence of 78 WRKY TFs evenly distributed across eight chromosomes in chickpea [4]. Furthermore, in chickpea seven genes including ARP6 (actin-related protein), PIE1 (photoperiod independent early flowering 1), two SEF (serrated leaf and early flowering), and three $H 2 A Z s$ (histone $2 \mathrm{~A}$ variant-Z, a thermosensor in plants) having homology with chromatin remodeling complexes (SWR1) in Arabidopsis were identified and analyzed for their expression under heat stress [170]. Of the seven genes, PIE1 was up-regulated during podding but down regulated at the seedling stage. Higher tissue-specific expression of PIE1 and SEF genes was observed in root, flower, pod wall, and grain tissues than in shoots. During pod development, all three $H 2 A Z$ genes might function as thermosensors, with greater downregulation within $15 \mathrm{~min}, 1$ and $6 \mathrm{~h}$ of the heat stress treatment [170].

"HSP90" is an important gene family for heat tolerance in legumes. In cool season grain legumes, protein sequences have been examined for the presence of histidine kinaselike ATPases (HATPase c) and HSP90 motifs. In chickpea, five HSP90 genes have been identified [166] and the proteins encoded by these genes ranged from 648 to 818 amino acids in length with isoelectric points ranging from 4.79 to 5.45 suggesting the conserved nature of HSP90 proteins across the different legumes. Expression pattern of AP2/ERF and HSP90 in chickpea under heat stress and RNA-seq data generated from leaf, root and flower tissues at vegetative and reproductive stages revealed a unique set of $A P 2 / E R F$ genes that expressed in different tissues [166]. In the same study, genes Ca_01566, Ca_14133 and Ca_22585 were down regulated, whereas $\mathrm{Ca}$ _14133, $\mathrm{Ca}$ _02170,Ca_02170 and $\mathrm{Ca} 23799$ were up-regulated in the vegetative tissues of heat-tolerant and heat-sensitive genotypes. However, in reproductive tissues, $\mathrm{Ca}$ _02170, Ca_08436, $\mathrm{Ca}$ _00673 and $\mathrm{Ca}$ _08436 were up-regulated and Ca_23799 and Ca_22585 were down regulated. Expression results prompt the identification of probable tissue and stage-specific candidate genes, which can counteract the given stress condition. Furthermore, proteomics analysis has identified 482 heat-responsive proteins in the tolerant genotypes [171]. Besides, other proteins like pyrroline-5-carboxylate synthase (P5CS) acetyl-CoA carboxylase, ribulose-1,5-bisphosphate carboxylase/oxygenase (RuBisCO), ATP synthase, sucrose synthase, phenylalanine ammonia-lyase (PAL) 2, glycosyltransferase and late embryogenesis abundant (LEA) proteins have also showed strong association with heat tolerance in chickpea. Several crucial proteins were induced by heat exclusively in the heat-tolerant genotype. Accumulation of osmoprotectants, protected membrane transport, ribosome and secondary metabolite synthesis, activation of antioxidant and defense compounds, amino acid biosynthesis, and hormonal modulation identified using comparative proteome profiling and pathway analysis can be important mitigating strategies for heat tolerance in chickpea.

Functional genomics facilitates the elucidation of the important role of candidate genes for expression of tolerance against abiotic stress in crop plants [172-174]. Among cool season grain legumes, five HSP90 candidate genes (Ca_25811,Ca_23016,Ca_09743,Ca_17680 and $C a \_25602$ ) have been identified in chickpea through RNA-sequencing analysis of leaf, flower and roots at different growth stages [166]. Mining of the candidate genes for heat tolerance revealed 236 genes in $2.28 \mathrm{Mb}(44.6-46.9 \mathrm{Mb})$ region in CaLG05 and 550 genes in $6.50 \mathrm{Mb}(7.85-14.35 \mathrm{Mb})$ in CaLG06 in chickpea. Functional categorization showed association of many genes with biological processes (168 genes in CaLG05 and 365 genes in CaLG06) in the two genomic regions [172]. Gene ontology classification revealed that these putative candidate genes (11 in CaLG05 and 14 in CaLG06) known to function, directly or indirectly, as heat-stress response genes in several plant species. Of the 25 candidate genes, five genes encoded protein like farnesylated protein 6 (AtFP6), ethylene-responsive transcription factor ERF114, ethylene-responsive transcription factor CRF4, F-box protein SKP2B and ethylene-responsive transcription factor RAP2-11. These genes played key roles in heat acclimation and growth of plants under severe heat-stress condition [172]. Additionally, the role of several heat stress responsive proteins such as $\beta$-galactosidase, glucanase, sucrose synthase, cystathionine gamma-synthase, 1-aminocyclopropane-1-carboxylic acid oxidase, abscisate $\beta$-glucosyltransferase, late embryogenesis abundant proteins impart- 
ing heat stress tolerance in chickpea has been deciphered [171]. A total of five candidate genes, namely $\mathrm{Ca}$ _00060 (encoding membralin protein) underlying GA11 marker, $\mathrm{Ca}$ _12498 (encoding ribosomal protein) underlying CESSR159 marker, Ca_25724 (encoding transcription initiation factor TFIID) underlying NCPGR150, Ca_17429 (encoding GDP-fucose protein O-fucosyl transferase) underlying NCPGR13 marker and Ca_08534 (encoding pentatricopeptide repeat) underlying NCPGR202 were deciphered. Likewise, genes encoding various transcription factors (TFs) [170,172,175], ribosomal proteins [176], pentatricopeptide proteins [177,178], TIC, REF6, aspartic protease, cc-NBSLRR, RGA3 [175], and GDP-fucose protein [179] showed their contribution in various abiotic stress including HS tolerance in various crop.

In lentil, NGS-based transcriptome analysis provided opportunity to identify candidate genes expressed under biotic and abiotic stress conditions, including heat stress [2,180,181]. The transcriptome analysis of heat sensitive and tolerant genotypes led to the identification of candidate genes related to physiological and pollen phenotypes, cell wall, and secondary metabolism in lentil [181]. This study identified the genes for PDCB (plasmodesmata callose-binding protein 3), phosphatidylinositol/phosphatidylcholine transfer protein SFH13, CDP-diacylglycerol-glycerol-3-phosphate 3-phosphatidyltransferase 1 chloroplastic, probable GPAT2 (glycerol-3-phosphate acyltransferase 2), O-acyltransferase, and phosphatidylcholine diacylglycerol choline phosphotransferase. Those were up-regulated in tolerant genotype under heat stress. A gene encoding pyruvate phosphate dikinase identified under heat stress conditions has been found to be responsible for producing the phosphoenolpyruvate (PEP). This metabolite is an essential compound of shikimate pathway that is responsible for production of secondary metabolites involved in heat tolerance. These genes were involved in different pathways in cell wall formation and secondary metabolites production that were affected under heat stress [181]. In another study, 76 upregulated and 47 downregulated candidate genes have been identified at the late reproductive stage under heat-stress conditions and identified an important role of tryptophan biosynthesis under heat stress in lentil [58].

\subsection{1. microRNA}

Plant miRNAs are a class of small (20-24 nucleotides) ncRNAs that regulate gene expression negatively by either degradation of mRNA or by inhibiting translation [182]. Evidences have revealed that miRNAs play crucial role in plant responses to heat stress. However, stress-associated regulatory networks that involve the role and activity of miRNAs are not clearly understood. It is further complicated to unravel such mechanism by the fact that several genes are regulated by one miRNA and some genes are regulated by multiple miRNAs. In different plant species, miRNA genes has been reported to enhance desired agronomic traits due to their tissue-specific, stress- or senescence-induced and constitutive overexpression [183-186]. Furthermore, endogenous and artificial target mimicry, artificial miRNA genes, Meganucleases, TALENs, ZNFs, CRISPR/Cpf1 or CRISPR/Cas13a systems, CRISPR/Cas9 and pri-miRNA or mature miRNA topical delivery have been shown to be useful for modulating miRNA accumulation.

miRNA genes are up or down regulated in response to biotic [187] and abiotic (reviewed by Ferdous et al. [188], Hackenberg et al. [189]) stresses in numerous species including soybean, sugarcane (Saccharum officinarum L.), rice, maize, wheat and tomato (Solanum lycopersicum L.). Studies on the expression or accumulation of these miRNAs have provided several lines of evidence to better understand the regulatory networks associated with defense mechanisms against different types of stresses. From these findings, several biotechnological tools have been applied for fine-tuning these networks and improving tolerance to stresses in important crops. Specific and well-studied example of miRNA involved to diverse abiotic stresses includes miR398, particularly for heat stress. In Arabidopsis, miR398 has four target genes (CSD1, CSD2, Cox5b-1 and CCS1), which are highly conserved in land plants $[190,191]$. Among these, CSDs, which are closely related to copper/zinc superoxide dismutases, are important scavengers of reactive oxygen species 
(ROS) and CSD/CCS are involved in the negative regulation of accumulation of ROS [192]. They are also associated with heat shock protein (HSF) and heat shock factor (HSF) synthesis [193]. miR398 was shown to be rapidly induced in response to heat stress, accompanied by the down regulation of its target genes CSD1, CSD2, and CCS [194]. Transgenic plants expressing miR398-resistant versions of CSD1, CSD2 or CCS showed hypersensitivity to heat stress, while the $\operatorname{csd} 1, \operatorname{csd} 2$, and $\operatorname{css}$ mutants were more tolerant to heat stress, with increased HSF and HSP levels [193,195]. In addition, miR398 and its target CSDs were also found in the heat stress responses of Brassica rapa and Populus tomentosa $[149,196]$, indicating that the mi R398-CSD/CCS pathway is widely involved in the heat stress response in plants.

Many miRNAs have been utilized by direct cloning and sequencing in several legumes including M. truncatula, chickpea, common bean, peanut, soybean and lotus, $[197,198]$. It has been demonstrated that both conserved as well as novel miRNAs are present in these species that may help in regulation of legume species-specific cell processes [197]. A total of 1256 sequences that belong to 285 miRNA families have been reported from legumes in a publicly available miRNA database, miRBase (http:/ / www.sanger.ac.uk/cgi-bin/ Rfam/mirna/browse.pl, accessed on 19 March 2013). Several sets of novel species specific (legume) miRNAs have been reported, including novel (87) and conserved (42) miRNAs in soy bean [198-200]. In addition, excess of 100 novel miRNAs were identified in $M$. truncatula [201-203]. Further, 16 conserved and six stress responsive miRNA families have been identified in common bean [204]. Based on sequencing approach and computational predictions, a large number of miRNA gene families (482), miRNA precursors (1039) and mature miRNA (1114) sequences have been detected from soybean and related legume species [205]. Further, NGS technology has also been successfully used to systematically identify stress-associated miRNAs [206-212]. Recent studies in various plants species suggested that miRNAs play an important role in abiotic stress tolerance like drought, cold and salinity tolerance. These studies included conserved miRNAs such as miR164, miR169, miR171, miR396, miR398, miR399, miR408 and miR2118 [213,214]. However, few studies demonstrated role of miRNAs in heat stress response in cool season grain legumes. In the case of chickpeas, the role of miRNA for stress response has been examined. It has been demonstrated that overexpression of miR408 leads enhanced drought tolerance in chickpea through the regulation of copper accumulation. The miR408 overexpression results plantacyanin transcript repression to regulate DREB and other drought responsive genes [186]. This tool can largely aid in future breeding programmes for various biotic and abiotic stresses in legumes as in wheat 70 miRNA based SSR markers have been identified and validated on a set of 20 terminal heat-tolerant and heat-susceptible genotypes for developing heat tolerant cultivars through marker assisted selection [215].

\subsubsection{Signaling and Metabolic Pathways}

Different signaling and metabolic pathways expressed in response of heat stress at different stages have been extensively studied and one of the schematic networks describing the mechanisms by which heat stress regulates reproductive development of legumes through sugar metabolism and signaling has presented in Figure 3. 


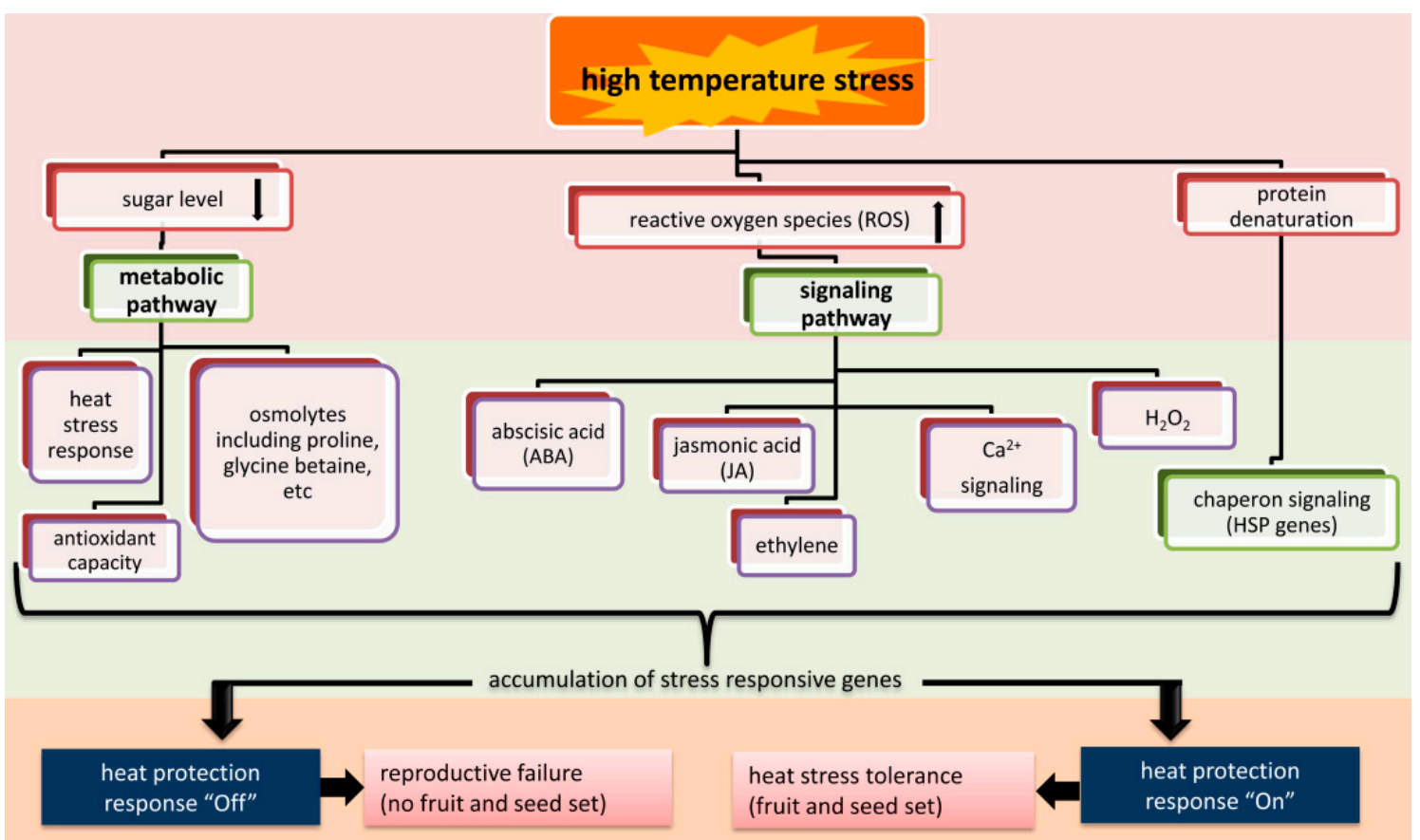

Figure 3. Flow-diagram showing how heat stress regulates reproductive development in legumes through sugar metabolic pathways and signalling pathway. The figures shows possible involvement of chain of chemicals/metabolites/signalling molecules in legume reproductive tolerance under heat stress.

In case of Arabidopsis, heat tolerance at seedling stage has been demonstrated. Mutants deficient in various pathways like hormone signaling including salicylic acid (SA), jasmonic acid (JA), abscisic acid (ABA), ROS systems and ROS regulatory systems and ethylene signaling as well as heat shock protein (HSP)-dependent pathways in the heat response have been analyzed [216]. Arabidopsis mutants deficient in S-nitrosoglutathione reductase (GSNOR), which metabolizes the nitric oxide (NO) adduct S-nitrosoglutathione, were more sensitive to heat stress compared with wild type [217], suggesting the involvement of GSNOR-dependent NO metabolism in heat tolerance of plants. Several heat sensors localized in different subcellular components have been identified. They include histone sensor in the nucleus, a calcium channel on the plasma membrane, and two unfolded protein sensors in the endoplasmic reticulum (ER) and the cytosol [218-221]. The deficiency in one of the heat sensors, cyclic nucleotide-gated channel 2 (CNGC2) resulted in enhanced heat tolerance in seedlings in addition to increased cytosolic $\mathrm{Ca}^{2+}$ level and enhanced accumulation of HSPs [222]. Furthermore, unfolded proteins in the ER and the cytosol have been identified to be linked with the heat sensing mechanism via ROS regulatory system [223]. (https: / / www.frontiersin.org/articles/10.3389/fpls.2018.00490/full, accessed on 4 December 2021)-B22Phytochrome B has been shown to be another heat sensor that mediates the switching of cellular status between growth-promoting mode and heat-acclimation mode [224,225]. Furthermore, involvement of key players of heat responses such as ROS regulatory systems, $\mathrm{Ca}^{2+}$ signaling, kinases and various hormones in defense responses has been demonstrated in previous studies [226-228]. However, cool season grain legume like chickpea and warm season grain legume like mungbean, increased $\mathrm{H}_{2} \mathrm{O}_{2}$ content and lipid peroxidation under heat stress were also observed [229]. Antioxidants, such as glutathione (GSH), ascorbic acid (AsA) and proline, play important roles in protecting plants from oxidative damage by scavenging ROS and thus enhance heat tolerance of legumes. Furthermore, there is often overproduction of different types of compatible organic solutes under abiotic stresses such as heat, drought, and salinity, among which proline and glycine betaine are important ones that act as osmoprotectants and ROS scavengers in stress tol- 
erance of plants [230]. In chickpea, exogenous application of proline and glycine betaine improved the growth of seedlings under heat stress [231,232]. Proline may enhance heat tolerance of chickpea through alleviating the inhibition of heat stress on key enzymes in carbon and oxidative metabolism in seedlings [233]. Proline translocation also appeared to play an important role in controlling heat tolerance of reproductive development in cowpea [234]. Proline transporter genes have been identified among five heat-tolerant QTLs relevant to cowpea reproduction [134]. Therefore, it is speculated that proline and its transportation might regulate the response of legume reproduction under heat stress, which will be further testified by more direct evidence. However, little is known about the role of different signaling pathways, metabolites or metabolic pathways for controlling heat stress tolerance in lentil and other cool season grain legumes. Only few transcriptome studies identified the candidate genes that encoded synthesis of secondary and primary metabolites involved in heat tolerance in lentil [43]. However, metabolomics study can directly exhibit the metabolite changes induced by stress as compared with transcriptomics. Therefore, there is a need to apply metabolomics for exploring the metabolites involved in heat-stress regulation in cool season grain legumes similar to other crop plants $[235,236]$. Further, a combination of transcriptomics with metabolomics can help to elucidate the gene-to-metabolite pathways as investigated in rice in the response to heat stress [237].

\section{Future Possibilities Genomic Intervention for Heat Stress Tolerance}

Knowledge of genomics enhanced in the past years can be used to intervene the development of heat stress tolerance in cool season grain legumes using the following ways.

\subsection{Epigenetic Modifications}

Environmental stresses including high temperature regulate the gene expression through DNA methylation, histone modification, miRNA expression modulation, alternate splicing etc. This is known as epigenetic modifications [238]. These changes help plants for better adaption under stress conditions [239] and provide thermotolerance [240]. It has been shown that priming of plants with mild or severe heat helps to maintain or acquire the heat stress memory, which increases themo-tolerance in subsequent exposure of heat-stressed primed plants [241,242]. The maintenance of thermotolerance is referred to as primingmediated heat-stress memory [243]. The roles of epigenetic factors have been shown to control priming responses and to maintain the heat stress priming memory [244]. In Arabidopsis, alternative splicing has been identified an important molecular mechanism that underpin the heat shock priming-induced memory for enhanced heat stress tolerance [245]. This alternative splicing is regulated by epigenetic histone modifications [246]. Thus, transcriptional pattern of genes in this study has been observed under the control of epigenetics through alternate splicing and marked epigenetically hyper-inducted loci upon recurring exposure to heat stress. However, identification molecular mechanism involved in epigenetic control of heat stress tolerance is still challenging [247]. However, in lentil (a cool season grain legume), heat priming of the seeds for $6 \mathrm{~h}$ at $35^{\circ} \mathrm{C}$ and a foliar treatment of $\gamma$-aminobutyric acid in combination helped to increase heat tolerance in sensitive genotypes by improving photosynthetic efficiency, chlorophyll concentration, and sucrose synthesis; and reducing the oxidative damage [248]. Epigenetic control of heat stress memory has also been identified through miRNA, which helps plants to adapt against heat stress through post-transcriptional regulators. Under heat stress, the expression of miRNAs and their targets are affected by DNA methylation [249]. This has been observed in several crop plants. For example, in poplar (Populus simonii), different heat-stress conditions methylated the miR393a, miR156i, miR167h, miR396e, and miR396g at CNG and CG sites [249,250]. However, efforts are needed to study the role of these in cool season grain legumes. 


\subsection{Mining Novel Allelic Variations for Heat Stress Tolerance}

Genomics has made it possible to mine allelic variation for target traits. The roles of these genomic advancements have been discussed in cool season legumes for developing heat tolerance genotypes.

\subsubsection{Genome Editing}

Genome sequences of several cool season grain legumes such as chickpea $[45,251]$, pea [252], lathyrus [253], lentil [254], common bean [255] and adzuki bean [65,256], are available publically. These genomic resources have provided opportunity to generate allelic variation for genes controlling targeted traits using genome editing techniques. Generated allelic variation has opened up new breeding possibilities for mining the alleles for any given desirable trait [257]. The CRISPR/Cas9 genome editing approach has been used widely for modifying a genome in a targeted manner in many crops including rice, tomato, potato, cotton, soybean, maize, sorghum and wheat [257-259]. The genome editing produces novel genetic variability through engineering and repairing of pathways, and introduction of specific point mutations or insertions [260]. In the past years, efforts have been made to exploit the genome editing for enhancing heat stress tolerance by targeting genes for ethylene response and TFs in several crops [261-264]. In cool season grain legumes, genome editing of targeted genes has not been used for heat stress tolerance. However, in chickpeas, CRISPR/Cas9 editing was used for the 4-coumarate ligase (4CL) and Reveille 7 (RVE7) genes, which were associated with drought tolerance leading to targeted mutagenesis [265]. In addition to this, CRISPR/Cas9-based genome editing has also used for a number of genes in other legume crops including model legume species [266].

\subsubsection{Targeting-Induced Local Lesions in Genome (TILLING)}

Genomic-based TILLING (targeting induced local lesions in genome) approach has provided an opportunity to identify allelic variation for gene controlling a trait of interest [267]. For TILLING, a mutant population generated through ethyl methane sulfonate(EMS), which produces point mutations distributed randomly in the genome, is required for identifying individuals with mutations in the target gene [268]. This has been used mainly for quality traits in several crops. One of the advantages is related with this approach that transgenic plants are not needed to generate a mutagenesis population. This approach has not been used to identify the allelic variation for a gene involved in $g$ heat stress tolerance in cool season grain legumes. However, in other crops, TILLING approach has been used to screen mutagenesis population for mutations in the HSP genes. For example, new alleles for small Hsp26 (sHsp26) genes were identified through TILLING that were found suitable for enhancing heat tolerance in wheat [269]. A mutated HSP gene enhanced heat tolerance in tomato has been identified using TILLING approach [270]. In common bean, TILLING population has been generated that can be used to screen mutation in the genes responsible heat stress tolerance [271].

\subsection{Genomics of Underground Traits}

Heat tolerance studies in cool season grain legumes have been focused mostly on above ground traits. However, in other crops, studies demonstrated that high temperature of soil highly affects the growth and development of plants than high air temperature under heat stress and thus roots also show their sensitivity to heat stress [272-274]. Thus, expression of pathways and proteins for thermo-tolerance in roots may be different than above-ground traits imparting in heat stress tolerance. Therefore, focuses have been given in other crops to studying the impact of heat stress on roots for enhancing knowledge of underlying mechanism and pathways involved in heat stress tolerance. Proteomics is a powerful approach to discover the proteins and pathways that are crucial for stress responsiveness and tolerance. Therefore, proteomic proofing has been done in Agrostis grass species that found up-regulation of sucrose synthase, glutathione-S-transferase and superoxide dismutase. This study also showed that heat shock protein Sti (stress-inducible 
protein) may contribute to the superior root thermotolerance and high phosphorylation of fructose-biphosphate aldolase under heat stress [272]. Proteomic knowledge in association with genomics helps to know the genes and pathways control the thermos-tolerance in roots under heat stress. Thus, a genome-wide transcriptional and proteomic profiling of root traits under heat stress in soybean showed differential expression of 1849 and 3091 genes in root hairs and stripped roots, respectively, in response to heat stress. This study identified 10 key regulatory modules controlling the majority of the transcriptional response to heat stress. Proteomic analysis in this study identified a variety of proteins changed their expression under heat stress and most of them showed their role in thermotolerance, chromatin remodelling and post-transcriptional regulation [274]. Further efforts are required for genomics and proteomic studies in cool season grain legumes.

\subsection{Nanoparticles Based Genomics and Proteomics}

Nanotechnology is an emerging field for providing the new information on biological systems because interaction of nanoparticles with plants led to several morphological and physiological changes. Nanoparticles of minute sizes can penetrate in the cell organelles and nuclei leading to disruption of basic biological function and change in the structure and function of DNA $[275,276]$. Nanoparticles have both negative and positive effects on plants [277]. In a recent study, nanoparticles have been shown to have positive impact on plant by immunizing them against heat stress [278]. As nanoparticles made several changes in the profiling of proteins and transcriptomes, high-throughput transcriptomics, proteomics, and metabolomics approaches can help to understand these changes at molecular level in crop plants [279]. Thus, nanoproteomics and nanogenomics involving application of proteomics and genomics techniques aided by nanotechnology [280] may become more useful to understand biochemical and molecular responses crop plants for nanoparticles under heat stress.

\section{Concluding Remarks}

During the last two decades, significant progress has been made on heat-stress tolerance and its component traits including number of filled pods per plot, total number of seeds per plot, \% pod setting, chlorophyll concentration, photochemical reflectance index and canopy temperature, reproductive stem length, internode length and pod number in cool season grain legumes. Efforts have been made to develop the image-based techniques for high-throughput phenotyping of flowering intensity in cool season grain legumes [32]. In cool season grain legumes, significant progress has been made in development of genomic resources. However, the available information on genomics has not been fully utilized in breeding programmes. Limited efforts have been made to identify QTL/genes for heat stress tolerance. Moreover, all the identified genes have not been functionally validated. Therefore, sincere efforts are required to identify the functional and associated markers with heat stress tolerance in cool season grain legumes. These QTLs can be introgressed through marker aided conventional breeding in elite but heat sensitive grain legume cultivars. By the availability of knowledge about QTLs and markers, the use of molecular breeding to supplement conventional breeding will certainly give a new direction to legume breeding programmes. The availability of genome sequence for several cool season grain legumes has greatly helped in understanding the mechanism underlying stress tolerance in these crops. Further, it has become possible to achieve better resolution and improved understanding of genes expressed at transcriptome level under heat stress by applying NGS technology. It has been demonstrated that both conserved as well as novel miRNAs are present in legume crops like $M$. truncatula, chickpea, common bean, peanut, soybean and lotus that may help in regulation of legume species specific cell processes associated with heat shock protein (HSF) and heat shock factor (HSF) synthesis. The metabolomics study can directly exhibit the metabolite changes induced by stress as compared with transcriptomics. Only few transcriptome studies have identified the candidate genes that encode synthesis of secondary and primary metabolites involved in 
heat tolerance. Therefore, further progress in this direction needs to apply metabolomics for exploring the metabolites involved in heat-stress regulation in cool season grain legumes. In the future, genome editing and base editing using a variety of CRISPR/Cas9 systems can provide desirable mutants for traits imparting tolerance to heat stress in cool season grain legumes. Moreover, TILLING, genomics for underground traits, epigenetics and nanoparticle-based genomics and proteomics have opened up future possibilities for enhancing the heat-stress tolerance in cool season grain legumes.

Author Contributions: Conceptualization, J.K.; methodology, J.K.; validation, J.K., R.K. (Rahul Kumar) and I.D.; formal analysis, J.K.; investigation, J.K., D.S.G. and R.R.M.; resources, J.K. and I.D.; data curation, J.K.; writing-original draft preparation, J.K., R.R.M., S.S.; writing-review and editing, I.D., D.S.G., J.M., R.K. (Rahul Kumar), R.K. (Rajeev Kumar) and S.K.; visualization, S.K. and R.K. (Rajeev Kumar); supervision, J.K. and I.D.; project administration, J.K. and I.D.; funding acquisition, J.K., I.D. and J.M. All authors have read and agreed to the published version of the manuscript.

Funding: This research received no external funding.

Institutional Review Board Statement: Not applicable.

Informed Consent Statement: Not applicable.

Data Availability Statement: The study did not report any data.

Acknowledgments: The authors are thankful to the Head, Crop Improvement Division, ICAR-IIPR, Kanpur, India for providing the supports and facilities.

Conflicts of Interest: The authors declare no conflict of interest.

\section{References}

1. Srivastava, R.P.; Vasishtha, H. Genotypic variation in pigeonpea for protein, dietary fibre, fatty acids and lectins. Indian J. Agric. Biochem. 2012, 25, 111-115.

2. Kumar, J.; Sen Gupta, D.; Djalovic, I. Breeding, genetics, and genomics for tolerance against terminal heat in lentil: Current status and future directions. Legume Sci. 2020, 2, e38. [CrossRef]

3. Liu, Y.; Li, J.; Zhu, Y.; Jones, A.; Rose, R.J.; Song, Y. Heat stress in legume seed setting: Effects, causes, and future prospects. Front. Plant Sci. 2019, 10, 938. [CrossRef] [PubMed]

4. Kumar, K.; Srivastava, V.; Purayannur, S.; Kaladhar, V.C.; Cheruvu, P.J.; Verma, P.K. WRKY domain-encoding genes of a crop legume chickpea (Cicer arietinum L): Comparative analysis with Medicago truncatula WRKY family and characterization of group-III gene (s). DNA Res. 2016, 23, 225-239. [CrossRef] [PubMed]

5. Wang, L.; Ma, K.B.; Lu, Z.G.; Ren, S.X.; Jiang, H.R.; Cui, J.W.; Chen, G.; Teng, N.J.; Lam, H.M.; Jin, B. Differential physiological, transcriptomic and metabolomic responses of Arabidopsis leaves under prolonged warming and heat shock. BMC Plant Biol. 2020, 20, 1-5. [CrossRef] [PubMed]

6. Ridge, P.E.; Pye, D.L. The effects of temperature and frost at flowering on the yield of peas grown in a Mediterranean environment. Field Crops Res. 1985, 12, 339-346. [CrossRef]

7. Deva, C.R.; Urban, M.O.; Challinor, A.J.; Falloon, P.; Svitákova, L. Enhanced leaf cooling is a pathway to heat tolerance in common bean. Front. Plant Sci. 2020, 11, 19. [CrossRef]

8. Sita, K.; Sehgal, A.; Hanumantha Rao, B.; Nair, R.M.; Prasad, P.V.; Kumar, S.; Gaur, P.M.; Farooq, M.; Siddique, K.H.; Varshney, R.K.; et al. Food legumes and rising temperatures: Effects, adaptive functional mechanisms specific to reproductive growth stage and strategies to improve heat tolerance. Front. Plant Sci. 2017, 8, 1658. [CrossRef]

9. Gaur, P.M.; Samineni, S.; Krishnamurthy, L.; Kumar, S.; Ghanem, M.E.; Beebe, S.E.; Rao, I.M.; Chaturvedi, S.K.; Basu, P.S.; Nayyar, H.; et al. High temperature tolerance in grain legumes. Legume Perspect. 2015, 7, 23-24.

10. Gaur, P.M.; Samineni, S.; Thudi, M.; Tripathi, S.; Sajja, S.B.; Jayalakshmi, V.; Mannur, D.M.; Vijayakumar, A.G.; Ganga Rao, N.V.; Ojiewo, C.; et al. Integrated breeding approaches for improving drought and heat adaptation in chickpea (Cicer arietinum L.). Plant Breed. 2019, 138, 389-400. [CrossRef]

11. Ehlers, J.D.; Hall, A.E. Heat tolerance of contrasting cowpea lines in short and long days. Field Crops Res. 1998, 55, 11-21. [CrossRef]

12. Porch, T.G.; Blair, M.W.; Lariguet, P.; Galeano, C.; Pankhurst, C.E.; Broughton, W.J. Generation of a mutant population for TILLING common bean genotype BAT 93. J. Am. Soc. Hortic. Sci. 2009, 134, 348-355. [CrossRef]

13. Krishnamurthy, L.; Gaur, P.M.; Basu, P.S.; Chaturvedi, S.K.; Tripathi, S.; Vadez, V.; Rathore, A.; Varshney, R.K.; Gowda, C.L. Large genetic variation for heat tolerance in the reference collection of chickpea (Cicer arietinum L.) germplasm. Plant Genet. Resour. Charact. Util. 2011, 9, 59-69. [CrossRef] 
14. Porch, T.G.; Hall, A.E. Heat tolerance. In Genomics and Breeding for Climate-Resilient Crops; Kole, C., Ed.; Springer Publishing: Berlin, Germany, 2013; pp. 167-202.

15. Kumar, A.P.; McKeown, P.C.; Boualem, A.; Ryder, P.; Brychkova, G.; Bendahmane, A.; Sarkar, A.; Chatterjee, M.; Spillane, C TILLING by Sequencing (TbyS) for targeted genome mutagenesis in crops. Mol. Breed. 2017, 37, 14. [CrossRef]

16. Govindaraj, M.; Pattanashetti, S.K.; Patne, N.; Kanatti, A.A.; Ciftci, Y.O. Breeding cultivars for heat stress tolerance in staple food crops. In Next Generation Plant Breeding; Çiftçi, Y.O., Ed.; Intech Open: London, UK, 2018; pp. 45-74.

17. Kumar, J.; Sen Gupta, D.; Djalovic, I.; Kumar, S.; Siddique, K.H.M. Root-omics for drought tolerance in cool-season grain legumes Physiol. Plant. 2021, 172, 629-644. [CrossRef]

18. Andrews, M.; Hodge, S. Climate change, a challenge for cool season grain legume crop production. In Climate Change and Management of Cool Season Grain Legume Crops; Yadav, S., Redden, R., Eds.; Springer: Dordrecht, The Netherlands, 2010; pp. 1-9.

19. Farooq, M.; Nadeem, F.; Gogoi, N.; Ullah, A.; Alghamdi, S.S.; Nayyar, H.; Siddique, K.H.M. Heat stress in grain legumes during reproductive and grain-filling phases. Crop Pasture Sci. 2017, 68, 985-1005. [CrossRef]

20. Kudapa, H.; Ramalingam, A.; Nayakoti, S.; Chen, X.; Zhuang, W.J.; Liang, X.; Kahl, G.; Edwards, D.; Varshney, R.K. Functional genomics to study stress responses in crop legumes: Progress and prospects. Funct. Plant Biol. 2013, 40, 1221-1233. [CrossRef]

21. Rani, A.; Devi, P.; Jha, U.C.; Sharma, K.D.; Siddique, K.H.M.; Nayyar, H. Developing climate-resilient chickpea involving physiological and molecular approaches with a focus on temperature and drought stresses. Front. Plant Sci. 2020, 10, 1759. [CrossRef] [PubMed]

22. Tafesse, E.G. Heat Stress Resistance in Pea (Pisum sativum L.) Based on Canopy and Leaf Traits. Doctoral Dissertation, University of Saskatchewan, Saskatoon, SK, Canada, 2018.

23. Wahid, A.; Gelani, S.; Ashraf, M.; Foolad, M.R. Heat tolerance in plants: An overview. Environ. Exp. Bot. 2007, 61, 199-223. [CrossRef]

24. Lavania, D.; Siddiqui, M.H.; Al-Whaibi, M.H.; Singh, A.K.; Kumar, R.; Grover, A. Genetic approaches for breeding heat stress tolerance in faba bean (Vicia faba L.). Acta Physiol. Plant. 2015, 37, 1737. [CrossRef]

25. Matthews, P.; Marcellos, H. Faba Bean. AgFact P4-2-7, 2nd ed.; NSW Department of Primary Industries: Tamworth, UK, 2003.

26. Devasirvatham, V.; Gaur, P.M.; Mallikarjuna, N.; Raju, T.N.; Trethowan, R.M.; Tan, D.K. Reproductive biology of chickpea response to heat stress in the field is associated with the performance in controlled environments. Field Crops Res. 2013, 142, 9-19. [CrossRef]

27. Sehgal, A.; Sita, K.; Kumar, J.; Kumar, S.; Singh, S.; Siddique, K.H.; Nayyar, H. Effects of drought, heat and their interaction on the growth, yield and photosynthetic function of lentil (Lens culinaris Medikus) genotypes varying in heat and drought sensitivity. Front. Plant Sci. 2017, 8, 1776. [CrossRef] [PubMed]

28. Lai, K.S.; Kaothien-Nakayama, P.; Iwano, M.; Takayama, S. A TILLING resource for functional genomics in Arabidopsis thaliana accession C24. Genes Genet. Syst. 2012, 87, 291-297. [CrossRef] [PubMed]

29. Khan, H.R.; Paull, J.G.; Siddique, K.H.M.; Stoddard, F.L. Faba bean breeding for drought-affected environments: A physiological and agronomic perspective. Field Crops Res. 2010, 115, 279-286. [CrossRef]

30. Burke, J.J.; Chen, J. Enhancement of reproductive heat tolerance in plants. PLoS ONE 2015, 10, e0122933. [CrossRef]

31. Gao, G.; Tester, M.A.; Julkowska, M.M. The use of high-throughput phenotyping for assessment of heat stress-induced changes in Arabidopsis. Plant Phenomics 2020, 2020, 3723916. [CrossRef]

32. Kiran, B.A.; Chimmad, V.P. Evaluation of chickpea genotypes for heat stress under partially controlled condition (elevated temperature) in polybags. Int. J. Chem. Stud. 2018, 6, 3008-3011.

33. Zhang, C.; Craine, W.A.; McGee, R.J.; Vandemark, G.J.; Davis, J.B.; Brown, J.; Hulbert, S.H.; Sankaran, S. Image-based phenotyping of flowering intensity in cool-season crops. Sensors 2020, 20, 1450. [CrossRef]

34. Confalonieri, R.; Paleari, L.; Foi, M.; Movedi, E.; Vesely, F.M.; Thoelke, W.; Agape, C.; Borlini, G.; Ferri, I.; Massara, F.; et al. PocketPlant3D: Analysing canopy structure using a smartphone. Biosyst. Eng. 2017, 164, 1-12. [CrossRef]

35. Hui, F.; Zhu, J.; Hu, P.; Meng, L.; Zhu, B.; Guo, Y.; Li, B.; Ma, Y. Image-based dynamic quantification and high-accuracy 3D evaluation of canopy structure of plant populations. Ann. Bot. 2018, 121, 1079-1088. [CrossRef] [PubMed]

36. Di Gennaro, S.F.; Rizza, F.; Badeck, F.W.; Berton, A.; Delbono, S.; Gioli, B.; Toscano, P.; Zaldei, A.; Matese, A. UAV-based high-throughput phenotyping to discriminate barley vigour with visible and near-infrared vegetation indices. Int. J. Remote Sens. 2018, 39, 5330-5344. [CrossRef]

37. Zhao, C.; Zhang, Y.; Du, J.; Guo, X.; Wen, W.; Gu, S.; Wang, J.; Fan, J. Crop phenomics: Current status and perspectives. Front. Plant Sci. 2019, 10, 714. [CrossRef] [PubMed]

38. Furbank, R.T.; Jimenez-Berni, J.A.; George-Jaeggli, B.; Potgieter, A.B.; Deery, D.M. Field crop phenomics: Enabling breeding for radiation use efficiency and biomass in cereal crops. New Phytol. 2019, 223, 1714-1727. [CrossRef]

39. Bohra, A.; Jha, U.C.; Godwin, I.; Varshney, R.K. Genomic interventions for sustainable agriculture. Plant Biotechnol. J. 2020, 18, 2388-2405. [CrossRef]

40. Roorkiwal, M.; Bharadwaj, C.; Barmukh, R.; Dixit, G.P.; Thudi, M.; Gaur, P.M.; Chaturvedi, S.K.; Fikre, A.; Hamwieh, A.; Kumar S.; et al. Integrating genomics for chickpea improvement: Achievements and opportunities. Theor. Appl. Genet. 2020, 133, 1703-1720. [CrossRef]

41. Kumar, J.; Gupta, D.S. Prospects of next generation sequencing in lentil breeding. Mol. Biol. Rep. 2020, 47, 9043-9053. [CrossRef] [PubMed] 
42. Gupta, D.S.; Kumar, J.; Gupta, S.; Dubey, S.; Gupta, P.; Singh, N.P.; Sablok, G. Identification, development, and application of cross-species intron-spanning markers in lentil (Lens culinaris Medik.). Crop J. 2018, 6, 299-305. [CrossRef]

43. Kumar, J.; Sen Gupta, D.; Baum, M.; Varshney, R.K.; Kumar, S. Genomics-assisted lentil breeding: Current status and future strategies. Legume Sci. 2021, e71. [CrossRef]

44. Gaur, R.; Azam, S.; Jeena, G.; Khan, A.W.; Choudhary, S.; Jain, M.; Yadav, G.; Tyagi, A.K.; Chattopadhyay, D.; Bhatia, S. Highthroughput SNP discovery and genotyping for constructing a saturated linkage map of chickpea (Cicer arietinum L.). DNA Res. 2012, 19, 357-373. [CrossRef] [PubMed]

45. Varshney, R.K.; Song, C.; Saxena, R.K.; Azam, S.; Yu, S.; Sharpe, A.G.; Cannon, S.; Baek, J.; Rosen, B.D.; Tarzan, B.; et al. Draft genome sequence of chickpea (Cicer arietinum) provides a resource for trait improvement. Nat. Biotechnol. 2013, 31, 240-246. [CrossRef]

46. Garg, R.; Patel, R.K.; Tyagi, A.K.; Jain, M. De novo assembly of chickpea transcriptome using short reads for gene discovery and marker identification. DNA Res. 2011, 18, 53-63. [CrossRef] [PubMed]

47. Garg, R.; Patel, R.K.; Jhanwar, S.; Priya, P.; Bhattacharjee, A.; Yadav, G.; Bhatia, S.; Chattopadhyay, D.; Tyagi, A.K.; Jain, M. Gene discovery and tissue-specific transcriptome analysis in chickpea with massively parallel pyrosequencing and web resource development. Plant Physiol. 2011, 156, 1661-1678. [CrossRef] [PubMed]

48. Hiremath, P.J.; Farmer, A.; Cannon, S.B.; Woodward, J.; Kudapa, H.; Tuteja, R.; Kumar, A.; Bhanu Prakash, A.; Mulaosmanovic, B.; Gujaria, N.; et al. Large-scale transcriptome analysis in chickpea (Cicer arietinum L.) an orphan legume crop of the semi-arid tropics of Asia and Africa. Plant Biotechnol. J. 2011, 9, 922-931. [CrossRef] [PubMed]

49. Hiremath, P.J.; Kumar, A.; Penmetsa, R.V.; Farmer, A.; Schlueter, J.A.; Chamarthi, S.K.; Whaley, A.M.; Carrasquilla-Garcia, N.; Gaur, P.M.; Upadhyaya, H.D.; et al. Large-scale development of cost-effective SNP marker assays for diversity assessment and genetic mapping in chickpea and comparative mapping in legumes. Plant Biotechnol. J. 2012, 10, 716-732. [CrossRef] [PubMed]

50. Jhanwar, S.; Priya, P.; Garg, R.; Parida, S.K.; Tyagi, A.K.; Jain, M. Transcriptome sequencing of wild chickpea as a rich resource for marker development. Plant Biotechnol. J. 2012, 10, 690-702. [CrossRef] [PubMed]

51. Agarwal, G.; Jhanwar, S.; Priya, P.; Singh, V.K.; Saxena, M.S.; Parida, S.K.; Garg, R.; Tyagi, A.K.; Jain, M. Comparative analysis of kabuli chickpea transcriptome with desi and wild chickpea provides a rich resource for development of functional markers. PLoS ONE 2012, 7, e52443. [CrossRef] [PubMed]

52. Kaur, S.; Cogan, N.O.; Pembleton, L.W.; Shinozuka, M.; Savin, K.W.; Materne, M.; Forster, J.W. Transcriptome sequencing of lentil based on second-generation technology permits large-scale unigene assembly and SSR marker discovery. BMC Genom. 2011, 12, 265. [CrossRef]

53. Sharpe, A.G.; Ramsay, L.; Sanderson, L.A.; Fedoruk, M.J.; Clarke, W.E.; Li, R.; Kagale, S.; Vijayan, P.; Vandenberg, A.; Bett, K.E. Ancient orphan crop joins modern era: Gene-based SNP discovery and mapping in lentil. BMC Genom. 2013, 14, 1-3. [CrossRef]

54. Verma, P.; Shah, N.; Bhatia, S. Development of an expressed gene catalogue and molecular markers from the de novo assembly of short sequence reads of the lentil (Lens culinaris M edik.) transcriptome. Plant Biotechnol. J. 2013, 11, 894-905. [CrossRef]

55. Temel, H.Y.; Göl, D.; Akkale, H.B.; Kahriman, A.; Tanyolac, M.B. Single nucleotide polymorphism discovery through Illuminabased transcriptome sequencing and mapping in lentil. Turk. J. Agric. For. 2015, 39, 470-488. [CrossRef]

56. Singh, D.; Singh, C.K.; Tomar, R.S.; Pal, M. Genetics and molecular mapping of heat tolerance for seedling survival and pod set in lentil. Crop Sci. 2017, 57, 3059-3067. [CrossRef]

57. Pavan, S.; Bardaro, N.; Fanelli, V.; Marcotrigiano, A.R.; Mangini, G.; Taranto, F.; Catalano, D.; Montemurro, C.; De Giovanni, C.; Lotti, C.; et al. Genotyping by sequencing of cultivated lentil (Lens culinaris Medik.) highlights population structure in the Mediterranean gene pool associated with geographic patterns and phenotypic variables. Front. Genet. 2019, 10, 872. [CrossRef] [PubMed]

58. Kumar, J.; Gupta, D.S.; Kesari, R.; Verma, R.; Murugesan, S.; Basu, P.S.; Soren, K.R.; Gupta, S.; Singh, N.P. Comprehensive RNAseq analysis for identification of genes expressed under heat stress in lentil. Physiol. Plant. 2021, 173, 1785-1807. [CrossRef] [PubMed]

59. Gali, K.K.; Sackville, A.; Tafesse, E.G.; Lachagari, V.B.; McPhee, K.; Hybl, M.; Mikić, A.; Smýkal, P.; McGee, R.; Burstin, J.; et al Genome-wide association mapping for agronomic and seed quality traits of field pea (Pisum sativum L.). Front. Plant Sci. 2019, 10, 1538. [CrossRef]

60. Beji, S.; Fontaine, V.; Devaux, R.; Thomas, M.; Negro, S.S.; Bahrman, N.; Siol, M.; Aubert, G.; Burstin, J.; Hilbert, J.L.; et al. Genome-wide association study identifies favorable SNP alleles and candidate genes for frost tolerance in pea. BMC Genom. 2020, 21, 536. [CrossRef]

61. Leonforte, A.; Sudheesh, S.; Cogan, N.O.; Salisbury, P.A.; Nicolas, M.E.; Materne, M.; Forster, J.W.; Kaur, S. SNP marker discovery, linkage map construction and identification of QTLs for enhanced salinity tolerance in field pea (Pisum sativum L.). BMC Plant Biol. 2013, 13, 161. [CrossRef]

62. Gong, Y.M.; Xu, S.C.; Mao, W.H.; Hu, Q.Z.; Zhang, G.W.; Ding, J.; Li, Y.D. Developing new SSR markers from ESTs of pea (Pisum sativum L.). J. Zhejiang Univ. Sci. B 2010, 11, 702-707. [CrossRef]

63. Deulvot, C.; Charrel, H.; Marty, A.; Jacquin, F.; Donnadieu, C.; Lejeune-Hénaut, I.; Aubert, G. Highly-multiplexed SNP genotyping for genetic mapping and germplasm diversity studies in pea. BMC Genom. 2010, 11, 468. [CrossRef]

64. Cheng, P.; Holdsworth, W.; Ma, Y.; Coyne, C.J.; Mazourek, M.; Grusak, M.A.; Fuchs, S.; McGee, R.J. Association mapping of agronomic and quality traits in USDA pea single-plant collection. Mol. Breed. 2015, 35, 1-3. [CrossRef] 
65. Duarte, J.; Rivière, N.; Baranger, A.; Aubert, G.; Burstin, J.; Cornet, L.; Lavaud, C.; Lejeune-He'naut, I.; Martinant, J.P.; Pichon, J.P.; et al. Transcriptome sequencing for high throughput SNP development and genetic mapping in pea. BMC Genom. 2014, 15, 126. [CrossRef]

66. Sindhu, A.; Ramsay, L.; Sanderson, L.A.; Stonehouse, R.; Li, R.; Condie, J.; Shunmugam, A.S.; Liu, Y.; Jha, A.B.; Diapari, M.; et al. Gene-based SNP discovery and genetic mapping in pea. Theor. Appl. Genet. 2014, 127, 2225-2241. [CrossRef]

67. Franssen, S.U.; Shrestha, R.P.; Bräutigam, A.; Bornberg-Bauer, E.; Weber, A.P. Comprehensive transcriptome analysis of the highly complex Pisum sativum genome using next generation sequencing. BMC Genom. 2011, 12, 227. [CrossRef]

68. Ferraro, K.; Jin, A.L.; Nguyen, T.D.; Reinecke, D.M.; Ozga, J.A.; Ro, D.K. Characterization of proanthocyanidin metabolism in pea (Pisum sativum) seeds. BMC Plant Biol. 2014, 14, 238. [CrossRef]

69. Tayeh, N.; Aluome, C.; Falque, M.; Jacquin, F.; Klein, A.; Chauveau, A.; Bérard, A.; Houtin, H.; Rond, C.; Kreplak, J.; et al. Development of two major resources for pea genomics: The GenoPea 13.2 K SNP Array and a high-density, high-resolution consensus genetic map. Plant J. 2015, 84, 1257-1273. [CrossRef]

70. Sudheesh, S.; Sawbridge, T.I.; Cogan, N.O.; Kennedy, P.; Forster, J.W.; Kaur, S. De novo assembly and characterisation of the field pea transcriptome using RNA-Seq. BMC Genom. 2015, 16, 611. [CrossRef] [PubMed]

71. Alves-Carvalho, S.; Aubert, G.; Carrère, S.; Cruaud, C.; Brochot, A.L.; Jacquin, F.; Klein, A.; Martin, C.; Boucherot, K.; Kreplak, J.; et al. Full-length de novo assembly of RNA-seq data in pea (Pisum sativum L.) provides a gene expression atlas and gives insights into root nodulation in this species. Plant J. 2015, 84, 1-19. [CrossRef]

72. Zhukov, V.A.; Zhernakov, A.I.; Kulaeva, O.A.; Ershov, N.I.; Borisov, A.Y.; Tikhonovich, I.A. De novo assembly of the pea (Pisum sativum L.) nodule transcriptome. Int. J. Genom. 2015, 2015, 695947. [CrossRef]

73. Kerr, S.C.; Gaiti, F.; Beveridge, C.A.; Tanurdzic, M. De novo transcriptome assembly reveals high transcriptional complexity in Pisum sativum axillary buds and shows rapid changes in expression of diurnally regulated genes. BMC Genom. 2017, 18, 221. [CrossRef] [PubMed]

74. Huang, S.; Gali, K.K.; Lachagari, R.V.; Chakravartty, N.; Bueckert, R.; Tarzan, B.; Warkentin, T.D. Identification of heat responsive genes in pea stipules and anthers through transcriptional profiling. bioRxiv 2021. [CrossRef]

75. Yang, T.; Fang, L.; Zhang, X.; Hu, J.; Bao, S.; Hao, J.; Li, L.; He, Y.; Jiang, J.; Wang, F.; et al. High-throughput development of SSR markers from pea (Pisum sativum L.) based on next generation sequencing of a purified Chinese commercial variety. PLoS ONE 2015, 10, e0139775. [CrossRef]

76. Mishra, R.K.; Gangadhar, B.H.; Nookaraju, A.; Kumar, S.; Park, S.W. Development of EST-derived SSR markers in pea (Pisum sativum) and their potential utility for genetic mapping and transferability. Plant Breed. 2012, 131, 118-124. [CrossRef]

77. Kaur, S.; Pembleton, L.W.; Cogan, N.O.; Savin, K.W.; Leonforte, T.; Paull, J.; Materne, M.; Forster, J.W. Transcriptome sequencing of field pea and faba bean for discovery and validation of SSR genetic markers. BMC Genom. 2012, 13, 104. [CrossRef]

78. Yang, T.; Jiang, J.; Burlyaeva, M.; Hu, J.; Coyne, C.J.; Kumar, S.; Redden, R.; Sun, X.; Wang, F.; Chang, J.; et al. Large-scale microsatellite development in grasspea (Lathyrus sativus L.), an orphan legume of the arid areas. BMC Plant Biol. 2014, 14, 65. [CrossRef] [PubMed]

79. Hao, X.; Yang, T.; Liu, R.; Hu, J.; Yao, Y.; Burlyaeva, M.; Wang, Y.; Ren, G.; Zhang, H.; Wang, D.; et al. An RNA sequencing transcriptome analysis of grasspea (Lathyrus sativus L.) and development of SSR and KASP markers. Front. Plant Sci. 2017, 8, 1873. [CrossRef] [PubMed]

80. Almeida, N.F.; Krezdorn, N.; Rotter, B.; Winter, P.; Rubiales, D.; Vaz Patto, M.C. Lathyrus sativus transcriptome resistance response to Ascochyta lathyri investigated by deep SuperSAGE analysis. Front. Plant Sci. 2015, 6, 178. [CrossRef]

81. Almeida, N.F.; Leitão, S.T.; Krezdorn, N.; Rotter, B.; Winter, P.; Rubiales, D.; Patto, M.C. Allelic diversity in the transcriptomes of contrasting rust-infected genotypes of Lathyrus sativus, a lasting resource for smart breeding. BMC Plant Biol. 2014, 14, 376. [CrossRef]

82. Kaur, S.; Kimber, R.B.; Cogan, N.O.; Materne, M.; Forster, J.W.; Paull, J.G. SNP discovery and high-density genetic mapping in faba bean (Vicia faba L.) permits identification of QTLs for ascochyta blight resistance. Plant Sci. 2014, 217, 47-55. [CrossRef]

83. Mokhtar, M.M.; Hussein, E.H.; El-Assal, S.E.; Atia, M.A. Vf ODB: A comprehensive database of ESTs, EST-SSRs, mtSSRs, microRNA-target markers and genetic maps in Vicia faba. AoB Plants 2020, 12, plaa064. [CrossRef]

84. Khalifa, K.A.; Ibrahim, S.D.; El-Garhy, H.A.S.; Moustafa, M.M.M.; Maalouf, F.; Alsamman, A.M.; Hamwieh, A.; El Allali, A. Developing a new genic SSR primer database in faba bean (Vicia faba L.). J. Appl. Genet. 2021, 62, 373-387. [CrossRef]

85. Ray, H.; Bock, C.; Georges, F. Faba bean: Transcriptome analysis from etiolated seedling and developing seed coat of key cultivars for synthesis of proanthocyanidins, phytate, raffinose family oligosaccharides, vicine, and convicine. Plant Genome 2015, 8, 1-11. [CrossRef]

86. Ocaña, S.; Seoane, P.; Bautista, R.; Palomino, C.; Claros, G.M.; Torres, A.M.; Madrid, E. Large-scale transcriptome analysis in faba bean (Vicia faba L.) under Ascochyta fabae infection. PLoS ONE 2015, 10, e0135143.

87. Yang, T.; Bao, S.Y.; Ford, R.; Jia, T.J.; Guan, J.P.; He, Y.H.; Sun, X.L.; Jiang, J.Y.; Hao, J.J.; Zhang, X.Y.; et al. High-throughput novel microsatellite marker of faba bean via next generation sequencing. BMC Genom. 2012, 13, 602. [CrossRef]

88. Garzon, L.N.; Blair, M.W. Development and mapping of SSR markers linked to resistance-gene homologue clusters in common bean. Crop J. 2014, 2, 183-194. [CrossRef] 
89. Blair, M.W.; Hurtado, N.; Chavarro, C.M.; Muñoz-Torres, M.C.; Giraldo, M.C.; Pedraza, F.; Tomkins, J.; Wing, R. Gene-based SSR markers for common bean (Phaseolus vulgaris L.) derived from root and leaf tissue ESTs: An integration of the BMc series. BMC Plant Biol. 2011, 11, 50. [CrossRef] [PubMed]

90. Song, Q.; Jia, G.; Hyten, D.L.; Jenkins, J.; Hwang, E.Y.; Schroeder, S.G.; Osorno, J.M.; Schmutz, J.; Jackson, S.A.; McClean, P.E.; et al. SNP assay development for linkage map construction, anchoring whole-genome sequence, and other genetic and genomic applications in common bean. G3 Genes Genomes Genet. 2015, 5, 2285-2890. [CrossRef] [PubMed]

91. García-Fernández, C.; Campa, A.; Garzón, A.S.; Miklas, P.; Ferreira, J.J. GWAS of pod morphological and color characters in common bean. BMC Plant Biol. 2021, 21, 1-3. [CrossRef] [PubMed]

92. Erdogmus, S.; Ates, D.; Nemli, S.; Yagmur, B.; Asciogul, T.K.; Ozkuru, E.; Karaca, N.; Yilmaz, H.; Esiyok, D.; Tanyolac, M.B. Genome-wide association studies of $\mathrm{Ca}$ and $\mathrm{Mn}$ in the seeds of the common bean (Phaseolus vulgaris L.). Genomics 2020, 112, 4536-4546. [CrossRef]

93. Nkhata, W.; Shimelis, H.; Melis, R.; Chirwa, R.; Mzengeza, T.; Mathew, I.; Shayanowako, A. Genome-wide association analysis of bean fly resistance and agro-morphological traits in common bean. PLoS ONE 2021, 16, e0250729.

94. Nemli, S.; Asciogul, T.K.; Ates, D.; Esiyok, D.; Tanyolac, M.B. SNP identification through genotyping by sequencing and genomewide association study (GWAS) of pod traits in common bean. In Proceedings of the International Plant and Animal Genome Conference, San Diego, CA, USA, 10-12 January 2016; p. 19798.

95. Ferreira, J.J.; Murube, E.; Campa, A. Introgressed genomic regions in a set of near-isogenic lines of common bean revealed by genotyping-by-sequencing. Plant Genome 2017, 10, plantgenome2016.08.0081. [CrossRef]

96. $\mathrm{Wu}, \mathrm{L}$;; Chang, Y.; Wang, L.; Wu, J.; Wang, S. Genetic dissection of drought resistance based on root traits at the bud stage in common bean. Theor. Appl. Genet. 2021, 134, 1-15. [CrossRef]

97. Ramírez, M.; Graham, M.A.; Blanco-López, L.; Silvente, S.; Medrano-Soto, A.; Blair, M.W.; Hernández, G.; Vance, C.P.; Lara, M. Sequencing and analysis of common bean ESTs. building a foundation for functional genomics. Plant Physiol. 2005, 137, 1211-1227. [CrossRef]

98. Melotto, M.; Monteiro-Vitorello, C.B.; Bruschi, A.G.; Camargo, L.E. Comparative bioinformatic analysis of genes expressed in common bean (Phaseolus vulgaris L.) seedlings. Genome 2005, 48, 562-570. [CrossRef]

99. McClean, P.E.; Mamidi, S.; McConnell, M.; Chikara, S.; Lee, R. Synteny mapping between common bean and soybean reveals extensive blocks of shared loci. BMC Genom. 2010, 11, 184. [CrossRef] [PubMed]

100. Blair, M.W.; Fernandez, A.C.; Ishitani, M.; Moreta, D.; Seki, M.; Ayling, S.; Shinozaki, K. Construction and EST sequencing of full-length, drought stress cDNA libraries for common beans (Phaseolus vulgaris L.). BMC Plant Biol. 2011, 11, 1-15. [CrossRef] [PubMed]

101. Thibivilliers, S.; Joshi, T.; Campbell, K.B.; Scheffler, B.; Xu, D.; Cooper, B.; Nguyen, H.T.; Stacey, G. Generation of Phaseolus vulgaris ESTs and investigation of their regulation upon Uromyces appendiculatus infection. BMC Plant Biol. 2009, 9, 46. [CrossRef] [PubMed]

102. Garcia, R.A.; Rangel, P.N.; Brondani, C.; Martins, W.S.; Melo, L.C.; Carneiro, M.S.; Borba, T.C.; Brondani, R.P. The characterization of a new set of EST-derived simple sequence repeat (SSR) markers as a resource for the genetic analysis of Phaseolus vulgaris. BMC Genet. 2011, 12, 41. [CrossRef]

103. Kalavacharla, V.; Liu, Z.; Meyers, B.C.; Thimmapuram, J.; Melmaiee, K. Identification and analysis of common bean (Phaseolus vulgaris L.) transcriptomes by massively parallel pyrosequencing. BMC Plant Biol. 2011, 11, 135. [CrossRef] [PubMed]

104. Vlasova, A.; Capella-Gutiérrez, S.; Rendón-Anaya, M.; Hernández-Oñate, M.; Minoche, A.E.; Erb, I.; Câmara, F.; Prieto-Barja, P.; Corvelo, A.; Sanseverino, W.; et al. Genome and transcriptome analysis of the Mesoamerican common bean and the role of gene duplications in establishing tissue and temporal specialization of genes. Genome Biol. 2016, 17, 1-8. [CrossRef]

105. Samantara, K.; Reyes, V.P.; Agrawal, N.; Mohapatra, S.R.; Jena, K.K. Advances and trends on the utilization of multi-parent advanced generation intercross (MAGIC) for crop improvement. Euphytica 2021, 217, 189. [CrossRef]

106. Kitony, J.K.; Sunohara, H.; Tasaki, M.; Mori, J.-I.; Shimazu, A.; Reyes, V.P.; Yasui, H.; Yamagata, Y.; Yoshimura, A.; Yamasaki, M.; et al. Development of an Aus-derived nested association mapping (Aus-NAM) population in rice. Plants 2021, 10, 1255. [CrossRef]

107. Spindel, J.; Iwata, H. Genomic selection in rice breeding. In Rice Genomics, Genetics and Breeding; Sasaki, T., Ashikari, M., Eds.; Springer: Singapore, 2018; pp. 473-496.

108. Reyes, V.P.; Angeles-Shim, R.B.; Mendioro, M.S.; Manuel, M.C.C.; Lapis, R.S.; Shim, J.; Sunohara, H.; Nishiuchi, S.; Kikuta, M.; Makihara, D.; et al. Marker-assisted introgression and stacking of major qtls controlling grain number $(G n 1 a)$ and number of primary branching (WFP) to nerica cultivars. Plants 2021, 10, 844. [CrossRef]

109. Jaganathan, D.; Thudi, M.; Kale, S.; Azam, S.; Roorkiwal, M.; Gaur, P.M.; Kishor, P.K.; Nguyen, H.; Sutton, T.; Varshney, R.K. Genotyping-by-sequencing based intra-specific genetic map refines a "QTL-hotspot" region for drought tolerance in chickpea. Mol. Genet. Genom. 2015, 290, 559-571. [CrossRef] [PubMed]

110. Kujur, A.; Upadhyaya, H.D.; Shree, T.; Bajaj, D.; Das, S.; Saxena, M.S.; Badoni, S.; Kumar, V.; Tripathi, S.; Gowda, C.L.; et al. Ultra-high density intra-specific genetic linkage maps accelerate identification of functionally relevant molecular tags governing important agronomic traits in chickpea. Sci. Rep. 2015, 5, 9468. [CrossRef]

111. Ellis, T.H.N.; Turner, L.; Hellens, R.P.; Lee, D.; Harker, C.L.; Enard, C.; Domoney, C.; Davies, D.R.; Ambrose, M. Linkage maps in pea. Genetics 1992, 130, 649-663. [CrossRef] [PubMed] 
112. Verma, P.; Goyal, R.; Chahota, R.K.; Sharma, T.R.; Abdin, M.Z.; Bhatia, S. Construction of a genetic linkage map and identification of QTLs for seed weight and seed size traits in lentil (Lens culinaris Medik.). PLoS ONE 2015, 10, e0139666. [CrossRef] [PubMed]

113. Paul, P.J.; Samineni, S.; Thudi, M.; Sajja, S.B.; Rathore, A.; Das, R.R.; Khan, A.W.; Chaturvedi, S.K.; Lavanya, G.R.; Varshney, R.K.; et al. Molecular mapping of QTLs for heat tolerance in chickpea. Int. J. Mol. Sci. 2018, 19, 2166. [CrossRef] [PubMed]

114. Jha, U.C.; Kole, P.C.; Singh, N.P. QTL mapping for heat stress tolerance in chickpea (Cicer arietinum L.). Legume Res. Int. J. 2021, 44, 382-387. [CrossRef]

115. Singh, D.; Singh, C.K.; Taunk, J.; Jadon, V.; Pal, M.; Gaikwad, K. Genome wide transcriptome analysis reveals vital role of heat responsive genes in regulatory mechanisms of lentil (Lens culinaris Medikus). Sci. Rep. 2019, 9, 12976. [CrossRef]

116. Tafesse, E.G.; Gali, K.K.; Lachagari, V.B.; Bueckert, R.; Warkentin, T.D. Genome-wide association mapping for heat stress responsive traits in field pea. Int. J. Mol. Sci. 2020, 21, 2043. [CrossRef]

117. Bhat, J.A.; Ali, S.; Salgotra, R.K.; Mir, Z.A.; Dutta, S.; Jadon, V.; Tyagi, A.; Mushtaq, M.; Jain, N.; Singh, P.K.; et al. Genomic selection in the era of next generation sequencing for complex traits in plant breeding. Front. Genet. 2016, 7, 221. [CrossRef]

118. George, A.W.; Cavanagh, C. Genome-wide association mapping in plants. Theor. Appl. Genet. 2015, 128, 1163-1174. [CrossRef] [PubMed]

119. Verdeprado, H.; Kretzschmar, T.; Begum, H.; Raghavan, C.; Joyce, P.; Lakshmanan, P.; Cobb, J.N.; Collard, B.C. Association mapping in rice: Basic concepts and perspectives for molecular breeding. Plant Prod. Sci. 2018, 21, 159-176. [CrossRef]

120. Thudi, M.; Upadhyaya, H.D.; Rathore, A.; Gaur, P.M.; Krishnamurthy, L.; Roorkiwal, M.; Nayak, S.N.; Chaturvedi, S.K.; Basu, P.S.; Gangarao, N.V.; et al. Genetic dissection of drought and heat tolerance in chickpea through genome-wide and candidate gene-based association mapping approaches. PLoS ONE 2014, 9, e96758. [CrossRef] [PubMed]

121. Vijayalakshmi, K.; Fritz, A.K.; Paulsen, G.M.; Bai, G.; Pandravada, S.; Gill, B.S. Modeling and mapping QTL for senescence-related traits in winter wheat under high temperature. Mol. Breed. 2010, 26, 163-175. [CrossRef]

122. Paliwal, R.; Röder, M.S.; Kumar, U.; Srivastava, J.P.; Joshi, A.K. QTL mapping of terminal heat tolerance in hexaploid wheat (T. aestivum L.). Theor. Appl. Genet. 2012, 125, 561-575. [CrossRef]

123. Talukder, S.K.; Babar, M.A.; Vijayalakshmi, K.; Poland, J.; Prasad, P.V.; Bowden, R.; Fritz, A. Mapping QTL for the traits associated with heat tolerance in wheat (Triticum aestivum L.). BMC Genet. 2014, 15, 97. [CrossRef] [PubMed]

124. Shirdelmoghanloo, H.; Taylor, J.D.; Lohraseb, I.; Rabie, H.; Brien, C.; Timmins, A.; Martin, P.; Mather, D.E.; Emebiri, L.; Collins, N.C. A QTL on the short arm of wheat (Triticum aestivum L.) chromosome 3B affects the stability of grain weight in plants exposed to a brief heat shock early in grain filling. BMC Plant Biol. 2016, 16, 100. [CrossRef] [PubMed]

125. Sharma, D.K.; Torp, A.M.; Rosenqvist, E.; Ottosen, C.O.; Andersen, S.B. QTLs and potential candidate genes for heat stress tolerance identified from the mapping populations specifically segregating for Fv/Fm in wheat. Front. Plant Sci. 2017, 8, 1668. [CrossRef]

126. Maulana, F.; Ayalew, H.; Anderson, J.D.; Kumssa, T.T.; Huang, W.; Ma, X.F. Genome-wide association mapping of seedling heat tolerance in winter wheat. Front. Plant Sci. 2018, 9, 1272. [CrossRef]

127. Chopra, R.; Burow, G.; Burke, J.J.; Gladman, N.; Xin, Z. Genome-wide association analysis of seedling traits in diverse Sorghum germplasm under thermal stress. BMC Plant Biol. 2017, 17, 12. [CrossRef]

128. Ye, C.; Argayoso, M.A.; Redoña, E.D.; Sierra, S.N.; Laza, M.A.; Dilla, C.J.; Mo, Y.; Thomson, M.J.; Chin, J.; Delaviña, C.B.; et al Mapping QTL for heat tolerance at flowering stage in rice using SNP markers. Plant Breed. 2012, 131, 33-41. [CrossRef]

129. Ye, C.; Tenorio, F.A.; Argayoso, M.A.; Laza, M.A.; Koh, H.J.; Redoña, E.D.; Jagadish, K.S.; Gregorio, G.B. Identifying and confirming quantitative trait loci associated with heat tolerance at flowering stage in different rice populations. BMC Genet. 2015, 16, 41. [CrossRef] [PubMed]

130. Kilasi, N.L.; Singh, J.; Vallejos, C.E.; Ye, C.; Jagadish, S.V.; Kusolwa, P.; Rathinasabapathi, B. Heat stress tolerance in rice (Oryza sativa L.): Identification of quantitative trait loci and candidate genes for seedling growth under heat stress. Front. Plant Sci. 2018, 9, 1578. [CrossRef] [PubMed]

131. Frey, F.P.; Presterl, T.; Lecoq, P.; Orlik, A.; Stich, B. First steps to understand heat tolerance of temperate maize at adult stage: Identification of QTL across multiple environments with connected segregating populations. Theor. Appl. Genet. 2016, 129, 945-961. [CrossRef]

132. Marfo, K.O.; Hall, A.E. Inheritance of heat tolerance during pod set in cowpea. Crop Sci. 1992, 32, 912-918. [CrossRef]

133. Lucas, M.R.; Ehlers, J.D.; Huynh, B.L.; Diop, N.N.; Roberts, P.A.; Close, T.J. Markers for breeding heat-tolerant cowpea. Mol. Breed. 2013, 31, 529-536. [CrossRef]

134. Pottorff, M.; Roberts, P.A.; Close, T.J.; Lonardi, S.; Wanamaker, S.; Ehlers, J.D. Identification of candidate genes and molecular markers for heat-induced brown discoloration of seed coats in cowpea [Vigna unguiculata (L.) Walp]. BMC Genom. 2014, 15, 1. [CrossRef]

135. Kaga, A.; Han, O.K.; Wang, X.W.; Egawa, Y.; Tomooka, N.; Vaughan, D.A. Vigna angularis as a model for legume research. In "Conservation and Use of Wild Relatives of Crops", Proceedings of the Joint Department of Agriculture, Sri Lanka and National Institute of Agrobiological Sciences, Japan Workshop, Okinawa, Japan, 3 February 2003; Department of Agriculture: Peradeniya, Sri Lanka, 2003; pp. $51-74$.

136. Vaughan, D.A.; Tomooka, N.; Kaga, A. Azuki Bean [Vigna angularis (Wild.) Ohwi \& Ohashi]. In Genetic Resources Chromosome Engineering and Crop Improvement Series Grain Legumes; Singh, R.J., Jauhar, P.P., Eds.; Taylor \& Francis Publishing: Boca Raton, FL, USA, 2005; pp. 347-359. 
137. Sudheesh, S.; Lombardi, M.; Leonforte, A.; Cogan, N.O.; Materne, M.; Forster, J.W.; Kaur, S. Consensus genetic map construction for field pea (Pisum sativum L.), trait dissection of biotic and abiotic stress tolerance and development of a diagnostic marker for the er1 powdery mildew resistance gene. Plant Mol. Biol. Rep. 2015, 33, 1391-1403.

138. Desgroux, A.; L'anthoëne, V.; Roux-Duparque, M.; Rivière, J.P.; Aubert, G.; Tayeh, N.; Moussart, A.; Mangin, P.; Vetel, P.; Piriou, C.; et al. Genome-wide association mapping of partial resistance to Aphanomyces euteiches in pea. BMC Genom. 2016, 17, 124. [CrossRef]

139. Diapari, M.; Sindhu, A.; Warkentin, T.D.; Bett, K.; Tar'an, B. Population structure and marker-trait association studies of iron, zinc and selenium concentrations in seed of field pea (Pisum sativum L.). Mol. Breed. 2015, 35, 30. [CrossRef]

140. Ahmad, S.; Kaur, S.; Lamb-Palmer, N.D.; Lefsrud, M.; Singh, J. Genetic diversity and population structure of Pisum sativum accessions for marker-trait association of lipid content. Crop J. 2015, 3, 238-245. [CrossRef]

141. Leonforte, A.; Forster, J.W.; Redden, R.J.; Nicolas, M.E.; Salisbury, P.A. Sources of high tolerance to salinity in pea (Pisum sativum L.). Euphytica 2013, 189, 203-216. [CrossRef]

142. Klein, A.; Houtin, H.; Rond, C.; Marget, P.; Jacquin, F.; Boucherot, K.; Huart, M.; Rivière, N.; Boutet, G.; Lejeune-Hénaut, I.; et al. QTL analysis of frost damage in pea suggests different mechanisms involved in frost tolerance. Theor. Appl. Genet. 2014, 127, 1319-1930. [CrossRef] [PubMed]

143. Jiang, Y.; Diapari, M.; Bueckert, R.A.; Tar'an, B.; Warkentin, T.D. Population structure and association mapping of traits related to reproductive development in field pea. Euphytica 2017, 213, 1-20. [CrossRef]

144. Wang, L.; Yu, X.; Wang, H.; Lu, Y.Z.; de Ruiter, M.; Prins, M.; He, Y.K. A novel class of heat-responsive small RNAs derived from the chloroplast genome of Chinese cabbage (Brassica rapa). BMC Genom. 2011, 12, 289. [CrossRef] [PubMed]

145. Soares-Cavalcanti, N.M.; Belarmino, L.C.; Kido, E.A.; Pandolfi, V.; Marcelino-Guimarães, F.C.; Rodrigues, F.A.; Pereira, G.A.; Benko-Iseppon, A.M. Overall picture of expressed heat shock factors in Glycine max, Lotus japonicus and Medicago truncatula. Genet. Mol. Biol. 2012, 35, 247-259. [CrossRef]

146. González-Schain, N.; Dreni, L.; Lawas, L.M.; Galbiati, M.; Colombo, L.; Heuer, S.; Jagadish, K.S.; Kater, M.M. Genome-wide transcriptome analysis during anthesis reveals new insights into the molecular basis of heat stress responses in tolerant and sensitive rice varieties. Plant Cell Physiol. 2016, 57, 57-68. [CrossRef]

147. Agarwal, G.; Garg, V.; Kudapa, H.; Doddamani, D.; Pazhamala, L.T.; Khan, A.W.; Thudi, M.; Lee, S.H.; Varshney, R.K. Genomewide dissection of AP2/ERF and HSP90 gene families in five legumes and expression profiles in chickpea and pigeonpea. Plant Biotechnol. J. 2016, 14, 1563-1577. [CrossRef]

148. Simões-Araújo, J.L.; Rodrigues, R.L.; Liliane, B.D.; Mondego, J.M.; Alves-Ferreira, M.; Rumjanek, N.G.; Margis-Pinheiro, M. Identification of differentially expressed genes by cDNA-AFLP technique during heat stress in cowpea nodules. FEBS Lett. 2012, 515, 44-50. [CrossRef]

149. Kotak, S.; Larkindale, J.; Lee, U.; von Koskull-Doring, P.; Vierling, E.; Scharf, K.D. Complexity of the heat stress response in plants. Curr. Opin. Plant Biol. 2007, 10, 310-316. [CrossRef]

150. Kumar, R.; Lavania, D.; Negi, M.; Siddiqui, M.H.; Al-Whaibi, M.; Grover, A. Identification and characterization of a small heat shock protein 17.9-CII gene from faba bean (Vicia faba L.). Acta Physiol. Plant. 2015, 37, 190. [CrossRef]

151. Zhu, B.; Ye, C.; Lü, H.; Chen, X.; Chai, G.; Chen, J.; Wang, C. Identification and characterization of a novel heat shock transcription factor gene, GmHsfA1, in soybeans (Glycine max). J. Plant Res. 2006, 119, 247-256. [CrossRef] [PubMed]

152. Chen, X.J.; Ye, C.J.; Lu, H.Y.; Xu, M.X.; Zhang, L.M.; Wang, C.; Luo, S.P.; Zhu, B.G. Cloning of GmHSFA1 gene and its over expression leading to enhancement of heat tolerance in transgenic soybean. Yi Chuan = Hered. 2006, 28, 1411-1420. [CrossRef] [PubMed]

153. Lopes-Caitar, V.S.; de Carvalho, M.C.; Darben, L.M.; Kuwahara, M.K.; Nepomuceno, A.L.; Dias, W.P.; Abdelnoor, R.V.; MarcelinoGuimarães, F.C. Genome-wide analysis of the Hsp20 gene family in soybean: Comprehensive sequence, genomic organization and expression profile analysis under abiotic and biotic stresses. BMC Genom. 2013, 14, 577. [CrossRef] [PubMed]

154. Morimoto, R.I. Regulation of the heat shock transcriptional response: Cross talk between a family of heat shock factors, molecular chaperones and negative regulators. Genes Dev. 1998, 12, 3788-3796. [CrossRef] [PubMed]

155. Baniwal, S.K.; Bharti, K.; Chan, K.Y.; Fauth, M.; Ganguli, A.; Kotak, S.; Mishra, S.K.; Nover, L.; Port, M.; Scharf, K.D.; et al. Heat stress response in plants: A complex game with chaperones and more than twenty heat stress transcription factors. J. Biosci. 2004, 29, 471-487. [CrossRef] [PubMed]

156. Chen, L.; Song, Y.; Li, S.; Zhang, L.; Zou, C.; Yu, D. The role of WRKY transcription factors in plant abiotic stresses. Biochim. Biophys. Acta (BBA)-Gene Regul. Mech. 2012, 1819, 120-128. [CrossRef]

157. Nover, L. Heat Shock Response; CRC Press Publishing: Boca Raton, FL, USA, 1991

158. Baniwal, S.K.; Chan, K.Y.; Scharf, K.D.; Nover, L. Role of heat stress transcription factor HsfA5 as specific repressor of HsfA4. J. Biol. Chem. 2007, 282, 605-613. [CrossRef]

159. Kotak, S.; Port, M.; Ganguli, A.; Bicker, F.; Von Koskull-Döring, P. Characterization of C-terminal domains of Arabidopsis heat stress transcription factors (Hsfs) and identification of a new signature combination of plant class A Hsfs with AHA and NES motifs essential for activator function and intracellular localization. Plant J. 2004, 39, 98-112. [CrossRef]

160. Bharti, K.; Koskull-Döring, P.; Bharti, S.; Kumar, P.; Tintschl-Körbitzer, A.; Treuter, E.; Nover, L. Tomato heat stress transcription factor HsfB1 represents a novel type of general transcription coactivator with a histone-like motif interacting with the plant CREB binding protein ortholog HAC1. Plant Cell 2004, 16, 1521-1535. [CrossRef] 
161. Mizoi, J.; Shinozaki, K.; Yamaguchi-Shinozaki, K. AP2/ERF family transcription factors in plant abiotic stress responses. Biochim. Biophys. Acta (BBA)-Gene Regul. Mech. 2012, 1819, 86-96. [CrossRef]

162. Bett, K.; Ramsay, L.; Chan, C.; Sharpe, A.; Cook, D.; Penmetsa, R.V. Lentil v1.0 and beyond. In Proceedings of the XXIV Plant and Animal Genome Conference, San Diego, CA, USA, 10-12 January 2016; pp. 9-13.

163. Kreplak, J.; Madoui, M.A.; Cápal, P.; Novák, P.; Labadie, K.; Aubert, G.; Bayer, P.E.; Gali, K.K.; Syme, R.A.; Main, D.; et al. A reference genome for pea provides insight into legume genome evolution. Nat. Genet. 2019, 51, 1411-1422. [CrossRef]

164. Martin, L.; Fei, Z.; Giovannoni, J.; Rose, J.K. Catalyzing plant science research with RNA-seq. Front. Plant Sci. 2013, 4, 66. [CrossRef] [PubMed]

165. Kudapa, H.; Agarwal, G.; Doddamani, D.; Kumar, V.; Khan, A.W.; Chitikineni, A.; Varshney, R.K. Comprehensive transcriptome analysis to identify heat stress responsive genes in chickpea (Cicer arietinum L.). In Proceedings of the International Plant and Animal Genome Conference Asia, Singapore, 19-21 May 2014.

166. Yuan, C.; Li, C.; Zhao, X.; Yan, C.; Wang, J.; Mou, Y.; Sun, Q.; Shan, S. Genome-wide identification and characterization of HSP90-RAR1-SGT1-complex members from Arachis genomes and their responses to biotic and abiotic stresses. Front. Genet. 2021, 12, 689669. [CrossRef]

167. Deokar, A.A.; Kondawar, V.; Kohli, D.; Aslam, M.; Jain, P.K.; Karuppayil, S.M.; Varshney, R.K.; Srinivasan, R. The CarERF genes in chickpea (Cicer arietinum L.) and the identification of CarERF116 as abiotic stress responsive transcription factor. Funct. Integr. Genom. 2015, 15, 27-46. [CrossRef]

168. Zhang, J.; Li, J.; Liu, B.B.; Zhang, L.; Chen, J.; Lu, M.Z. Genome-wide analysis of the Populus Hsp90 gene family reveals differential expression patterns, localization, and heat stress responses. BMC Genom. 2013, 14, 532. [CrossRef] [PubMed]

169. Konda, A.K.; Farmer, R.; Soren, K.R.; Ps, S.; Setti, A. Structural modeling and molecular dynamics of a multi-stress responsive WRKY TF-DNA complex towards elucidating its role in stress signaling mechanisms in chickpea. J. Biomol. Struct. Dyn. 2018, 36, 2279-2291. [CrossRef] [PubMed]

170. Chidambaranathan, P.; Jagannadham, P.T.; Satheesh, V.; Jain, P.K.; Srinivasan, R. Expression analysis of six chromatin remodeling complex genes (SWR1) in chickpea in different tissues during heat stress. Indian Jouranl Genet. 2016, 76, 1-11. [CrossRef]

171. Parankusam, S.; Bhatnagar-Mathur, P.; Sharma, K.K. Heat responsive proteome changes reveal molecular mechanisms underlying heat tolerance in chickpea. Environ. Exp. Bot. 2017, 141, 132-144. [CrossRef]

172. Jha, U.C.; Nayyar, H.; Palakurthi, R.; Jha, R.; Valluri, V.; Bajaj, P.; Chitikineni, A.; Singh, N.P.; Varshney, R.K.; Thudi, M. Major QTLs and potential candidate genes for heat stress tolerance identified in chickpea (Cicer arietinum L.). Front. Plant Sci. 2021, 12, 655103. [CrossRef]

173. Kudapa, H.; Garg, V.; Chitikineni, A.; Varshney, R.K. The RNA-Seq-based high resolution gene expression atlas of chickpea (Cicer arietinum L.) reveals dynamic spatio-temporal changes associated with growth and development. Plant Cell Environ. 2018, 41, 2209-2225. [CrossRef]

174. Chidambaranathan, P.; Jagannadham, P.T.; Satheesh, V.; Kohli, D.; Basavarajappa, S.H.; Chellapilla, B.; Kumar, J.; Jain, P.K.; Srinivasan, R. Genome-wide analysis identifies chickpea (Cicer arietinum) heat stress transcription factors (Hsfs) responsive to heat stress at the pod development stage. J. Plant Res. 2018, 131, 525-542. [CrossRef] [PubMed]

175. Varshney, R.K.; Thudi, M.; Roorkiwal, M.; He, W.; Upadhyaya, H.D.; Yang, W.; Bajaj, P.; Cubry, P.; Rathore, A.; Jian, J.; et al Resequencing of 429 chickpea accessions from 45 countries provides insights into genome diversity, domestication and agronomic traits. Nat. Genet. 2019, 51, 857-864. [CrossRef] [PubMed]

176. Moin, M.; Bakshi, A.; Saha, A.; Dutta, M.; Madhav, S.M.; Kirti, P.B. Rice ribosomal protein large subunit genes and their spatio-temporal and stress regulation. Front. Plant Sci. 2016, 7, 1284. [CrossRef]

177. Xing, H.; Fu, X.; Yang, C.; Tang, X.; Guo, L.; Li, C.; Xu, C.; Luo, K. Genome-wide investigation of pentatricopeptide repeat gene family in poplar and their expression analysis in response to biotic and abiotic stresses. Sci. Rep. 2018, 8, 2817. [CrossRef] [PubMed]

178. Ravichandran, S.; Ragupathy, R.; Edwards, T.; Domaratzki, M.; Cloutier, S. MicroRNA-guided regulation of heat stress response in wheat. BMC Genom. 2019, 20, 488. [CrossRef] [PubMed]

179. Panter, P.E.; Kent, O.; Dale, M.; Smith, S.J.; Skipsey, M.; Thorlby, G.; Cummins, I.; Ramsay, N.; Begum, R.A.; Sanhueza, D.; et al. MUR1-mediated cell-wall fucosylation is required for freezing tolerance in Arabidopsis thaliana. New Phytol. 2019, 224, 1518-1531. [CrossRef]

180. Von Koskull-Doring, P.; Scharf, K.D.; Nover, L. The diversity of plant heat stress transcription factors. Trends Plant Sci. 2007, 12, 452-457. [CrossRef]

181. Kumar, J.; Choudhary, A.K.; Gupta, D.S.; Kumar, S. Towards exploitation of adaptive traits for climate-resilient smart pulses. Int. J. Mol. Sci. 2019, 20, 2971. [CrossRef]

182. Rogers, K.; Chen, X. Biogenesis, turnover, and mode of action of plant microRNAs. Plant Cell 2013, 25, 2383-2399. [CrossRef]

183. Dong, C.H.; Pei, H. Over-expression of miR397 improves plant tolerance to cold stress in Arabidopsis thaliana. J. Plant Biol. 2014, 57, 209-217. [CrossRef]

184. Zhang, B. MicroRNA: A new target for improving plant tolerance to abiotic stress. J. Exp. Bot. 2015, 66, 1749-1761. [CrossRef]

185. Trumbo, J.L.; Zhang, B.; Stewart, C.N., Jr. Manipulating microRNAs for improved biomass and biofuels from plant feedstocks. Plant Biotechnol. J. 2015, 13, 337-354. [CrossRef] 
186. Hajyzadeh, M.; Turktas, M.; Khawar, K.M.; Unver, T. miR408 overexpression causes increased drought tolerance in chickpea. Gene 2015, 555, 186-193. [CrossRef] [PubMed]

187. Gupta, O.P.; Sharma, P.; Gupta, R.K.; Sharma, I. Current status on role of miRNAs during plant-fungus interaction. Physiol. Mol. Plant Pathol. 2014, 5, 1-7. [CrossRef]

188. Ferdous, J.; Hussain, S.S.; Shi, B.J. Role of microRNAs in plant drought tolerance. Plant Biotechnol. J. 2015, 13, 293-305. [CrossRef] [PubMed]

189. Hackenberg, M.; Gustafson, P.; Langridge, P.; Shi, B.J. Differential expression of microRNAs and other small RNAs in barley between water and drought conditions. Plant Biotechnol. J. 2015, 13, 2-13. [CrossRef]

190. Sunkar, R.; Zhu, J.K. Novel and stress-regulated microRNAs and other small RNAs from Arabidopsis. Plant Cell 2014, 16, $2001-2019$. [CrossRef]

191. Zhu, C.; Ding, Y.; Liu, H. MiR398 and plant stress responses. Physiol. Plant. 2011, 143, 1-9. [CrossRef]

192. Sunkar, R.; Kapoor, A.; Zhu, J.K. Posttranscriptional induction of two Cu/Zn superoxide dismutase genes in Arabidopsis is mediated by downregulation of miR398 and important for oxidative stress tolerance. Plant Cell 2006, 18, 2051-2065. [CrossRef]

193. Lu, X.; Guan, Q.; Zhu, J. Downregulation of CSD2 by a heat-inducible miR398 is required for thermotolerance in Arabidopsis. Plant Signal. Behav. 2013, 8, e24952. [CrossRef] [PubMed]

194. Guan, Q.M.; Lu, X.Y.; Zeng, H.T.; Zhang, Y.Y.; Zhu, J.H. Heat stress induction of miR398 triggers a regulatory loop that is critical for thermotolerance in Arabidopsis. Plant J. 2013, 74, 840-851. [CrossRef] [PubMed]

195. Gurley, W.B. HSP101: A key component for the acquisition of thermotolerance in plants. Plant Cell 2000, 12, 457-460. [CrossRef]

196. Yu, X.; Wang, H.; Lu, Y.; de Ruiter, M.; Cariaso, M.; Prins, M.; van Tunen, A.; He, Y. Identification of conserved and novel microRNAs that are responsive to heat stress in Brassica rapa. J. Exp. Bot. 2012, 63, 1025-1038. [CrossRef] [PubMed]

197. Szittya, G.; Moxon, S.; Santos, D.M.; Jing, R.; Fevereiro, M.P.; Moulton, V.; Dalmay, T. High-throughput sequencing of Medicago truncatula short RNAs identifies eight new miRNA families. BMC Genom. 2008, 9, 593. [CrossRef] [PubMed]

198. Subramanian, S.; Fu, Y.; Sunkar, R.; Barbazuk, W.B.; Zhu, J.K.; Yu, O. Novel and nodulation-regulated microRNAs in soybean roots. BMC Genom. 2008, 9, 160. [CrossRef] [PubMed]

199. Wang, Y.; Li, P.; Cao, X.; Wang, X.; Zhang, A.; Li, X. Identification and expression analysis of miRNAs from nitrogen-fixing soybean nodules. Biochem. Biophys. Res. Commun. 2009, 378, 799-803. [CrossRef]

200. Joshi, T.; Yan, Z.; Libault, M.; Jeong, D.H.; Park, S.; Green, P.J.; Sherrier, D.J.; Farmer, A.; May, G.; Meyers, B.C.; et al. Prediction of novel miRNAs and associated target genes in Glycine Max. BMC Bioinform. 2010, 11, 1-9. [CrossRef]

201. Jagadeeswaran, G.; Zheng, Y.; Li, Y.F.; Shukla, L.I.; Matts, J.; Hoyt, P.; Macmil, S.L.; Wiley, G.B.; Roe, B.A.; Zhang, W.; et al. Cloning and characterization of small RNAs from Medicago truncatula reveals four novel legume-specific microRNA families. New Phytol. 2009, 184, 85-98. [CrossRef] [PubMed]

202. Lelandais-Brière, C.; Naya, L.; Sallet, E.; Calenge, F.; Frugier, F.; Hartmann, C.; Gouzy, J.; Crespi, M. Genome-wide Medicago truncatula small RNA analysis revealed novel microRNAs and isoforms differentially regulated in roots and nodules. Plant Cell 2009, 21, 2780-2796. [CrossRef]

203. Sun, Z.; Wang, Y.; Mou, F.; Tian, Y.; Chen, L.; Zhang, S.; Jiang, Q.; Li, X. Genome-wide small rna analysis of soybean reveals auxin-responsive microRNAs that are differentially expressed in response to salt stress in root apex. Front. Plant Sci. 2016, 6, 1273. [CrossRef]

204. Arenas-Huertero, C.; Pérez, B.; Rabanal, F.; Blanco-Melo, D.; De la Rosa, C.; Estrada-Navarrete, G.; Sanchez, F.; Covarrubias, A.A.; Reyes, J.L. Conserved and novel miRNAs in the legume Phaseolus vulgaris in response to stress. Plant Mol. Biol. 2009, 70, 385-401. [CrossRef]

205. Ramesh, V.; Admane, N.; Husain, S.M. Small RNAs landscape (sRNAome) of soybean [Glycine max (L.)]: Biogenesis, vital functions and potential applications. Plant Knowl. J. 2013, 2, 24-37.

206. Li, H.; Dong, Y.; Yin, H.; Wang, N.; Yang, J.; Liu, X.; Wang, Y.; Wu, J.; Li, X. Characterization of the stress associated microRNAs in Glycine max by deep sequencing. BMC Plant Biol. 2011, 11, 170. [CrossRef]

207. Chen, L.; Zhang, Y.; Ren, Y.; Xu, J.; Zhang, Z.; Wang, Y. Genome wide identification of cold-responsive and new microRNAs in Populus tomentosa by high-throughput sequencing. Biochem. Biophys. Res. Commun. 2011, 417, 892-896. [CrossRef]

208. Wang, T.; Chen, L.; Zhao, M.; Tian, Q.; Zhang, W.H. Identification of drought-responsive microRNAs in Medicago truncatula by genome-wide high-throughput sequencing. BMC Genom. 2011, 12, 367. [CrossRef]

209. Zhou, Z.S.; Zeng, H.Q.; Liu, Z.P.; Yang, Z.M. Genome-wide identification of Medicago truncatula microRNAs and their targets reveals their differential regulation by heavy metal. Plant Cell Environ. 2012, 35, 86-99. [CrossRef] [PubMed]

210. Samad, A.F.; Sajad, M.; Nazaruddin, N.; Fauzi, I.A.; Murad, A.; Zainal, Z. MicroRNA and transcription factor: Key players in plant regulatory network. Front. Plant Sci. 2017, 8, 565. [CrossRef] [PubMed]

211. Khandal, H.; Parween, S.; Roy, R.; Meena, M.K.; Chattopadhyay, D. MicroRNA profiling provides insights into post-transcriptional regulation of gene expression in chickpea root apex under salinity and water deficiency. Sci. Rep. 2017, 7, 4632. [CrossRef]

212. Sun, X.; Lin, L.; Na, S. Regulation mechanism of microRNA in plant response to abiotic stress and breeding. Mol. Biol. Rep. 2019, 46, 1447-1457. [CrossRef] [PubMed]

213. Liu, H.H.; Tian, X.; Li, Y.J.; Wu, C.A.; Zheng, C.C. Microarray-based analysis of stress-regulated microRNAs in Arabidopsis thaliana. RNA 2008, 14, 836-843. [CrossRef] [PubMed] 
214. Samad, A.F.A.; Ali, N.M.; Ismail, I.; Murad, A.M.A. Analysis of miRNAs targeting transcription factors in Persicaria minor induced by Fusarium oxysporum. AIP Conf. Proc. 2016, 1784, 020009.

215. Sihag, P.; Sagwal, V.; Kumar, A.; Balyan, P.; Mir, R.R.; Dhankher, O.P.; Kumar, U. Discovery of miRNAs and development of heat-responsive miRNA-SSR markers for characterization of wheat germplasm for terminal heat tolerance breeding. Front. Genet. 2021, 12, 699420. [CrossRef] [PubMed]

216. Larkindale, J.; Hall, J.D.; Knight, M.R.; Vierling, E. Heat stress phenotypes of Arabidopsis mutants implicate multiple signaling pathways in the acquisition of thermotolerance. Plant Physiol. 2005, 138, 882-897. [CrossRef]

217. Lee, U.; Wie, C.; Fernandez, B.O.; Feelisch, M.; Vierling, E. Modulation of nitrosative stress by S-nitrosoglutathione reductase is critical for thermotolerance and plant growth in Arabidopsis. Plant Cell 2008, 20, 786-802. [CrossRef] [PubMed]

218. Sugio, A.; Dreos, R.; Aparicio, F.; Maule, A.J. The cytosolic protein response as a subcomponent of the wider heat shock response in Arabidopsis. Plant Cell 2009, 21, 642-654. [CrossRef] [PubMed]

219. Che, P.; Bussell, J.D.; Zhou, W.; Estavillo, G.M.; Pogson, B.J.; Smith, S.M. Signaling from the endoplasmic reticulum activates brassinosteroid signaling and promotes acclimation to stress in Arabidopsis. Sci. Signal. 2010, 3, ra69. [CrossRef]

220. Kumar, S.V.; Wigge, P.A. H2A.Z-containing nucleosomes mediate the thermos sensory response in Arabidopsis. Cell 2010, 140, 136-147. [CrossRef]

221. Friedrich, T.; Faivre, L.; Bäurle, I.; Schubert, D. Chromatin-based mechanisms of temperature memory in plants. Plant Cell Environ. 2019, 42, 762-770. [CrossRef]

222. Finka, A.; Cuendet, A.F.; Maathuis, F.J.; Saidi, Y.; Goloubinoff, P. Plasma membrane cyclic nucleotide gated calcium channels control land plant thermal sensing and acquired thermotolerance. Plant Cell 2012, 24, 3333-3348. [CrossRef]

223. Sun, A.Z.; Guo, F.Q. Chloroplast retrograde regulation of heat stress responses in plants. Front. Plant Sci. 2016, 7, 398. [CrossRef] [PubMed]

224. Jung, J.H.; Domijan, M.; Klose, C.; Biswas, S.; Ezer, D.; Gao, M.; Khattak, A.K.; Box, M.S.; Charoensawan, V.; Cortijo, S.; et al. Phytochromes function as thermosensors in Arabidopsis. Science 2016, 354, 886-889. [CrossRef] [PubMed]

225. Quint, M.; Delker, C.; Franklin, K.A.; Wigge, P.A.; Halliday, K.J.; van Zanten, M. Molecular and genetic control of plant thermomorphogenesis. Nat. Plants 2016, 2, 15190. [CrossRef] [PubMed]

226. Zhang, H.; Hong, Y.; Huang, L.; Li, D.; Song, F. Arabidopsis AtERF014 acts as a dual regulator that differentially modulates immunity against Pseudomonas syringae pv. tomato and Botrytis cinerea. Plant Physiol. 2016, 6, 30251.

227. Zhang, L.; Zhang, F.; Melotto, M.; Yao, J.; He, S.Y. Jasmonate signaling and manipulation by pathogens and insects. J. Exp. Bot. 2017, 68, 1371-1385. [CrossRef] [PubMed]

228. Luo, X.; Xu, N.; Huang, J.; Gao, F.; Zou, H.; Boudsocq, M.; Coaker, G.; Liu, J. A lectin receptor-like kinase mediates patterntriggered salicylic acid signaling. Plant Physiol. 2017, 174, 2501-2514. [CrossRef]

229. Awasthi, R.; Gaur, P.; Turner, N.C.; Vadez, V.; Siddique, K.H.M.; Nayyar, H. Effects of individual and combined heat and drought stress during seed filling on the oxidative metabolism and yield of chickpea (Cicer arietinum) genotypes differing in heat and drought tolerance. Crop Pasture Sci. 2017, 68, 823-841. [CrossRef]

230. Ashraf, M.; Foolad, M.R. Roles of glycine betaine and proline in improving plant abiotic stress resistance. Environ. Exp. Bot. 2007, 59, 206-216. [CrossRef]

231. Kaushal, N.; Gupta, K.; Bhandhari, K.; Kumar, S.; Thakur, P.; Nayyar, H. Proline induces heat tolerance in chickpea (Cicer arietinum L.) plants by protecting vital enzymes of carbon and antioxidative metabolism. Physiol. Mol. Biol. Plants 2011, 17, 203-213. [CrossRef]

232. Kumar, S.; Kaushal, N.; Nayyar, H.; Gaur, P. Abscisic acid induces heat tolerance in chickpea (Cicer arietinum L.) seedlings by facilitated accumulation of osmoprotectants. Acta Physiol. Plant. 2012, 34, 1651-1658. [CrossRef]

233. Kaushal, N.; Awasthi, R.; Gupta, K.; Gaur, P.; Siddique, H.M.K.; Nayyar, H. Heat-stress-induced reproductive failures in chickpea (Cicer arietinum) are associated with impaired sucrose metabolism in leaves and anthers. Funct. Plant Biol. 2013, 40, 1334-1349. [CrossRef]

234. Mutters, R.G.; Hall, A.E.; Patel, P.N. Photoperiod and light quality effects on cowpea floral development at high temperatures. Crop Sci. 1979, 29, 1501-1505. [CrossRef]

235. De Leonardis, A.M.; Fragasso, M.; Beleggia, R.; Ficco, D.B.; De Vita, P.; Mastrangelo, A.M. Effects of heat stress on metabolite accumulation and composition, and nutritional properties of durum wheat grain. Int. J. Mol. Sci. 2015, 16, 30382-30404. [CrossRef] [PubMed]

236. Obata, T.; Witt, S.; Lisec, J.; Palacios-Rojas, N.; Florez-Sarasa, I.; Yousfi, S.; Araus, J.L.; Cairns, J.E.; Fernie, A.R. Metabolite profiles of maize leaves in drought, heat, and combined stress field trials reveal the relationship between metabolism and grain yield. Plant Physiol. 2015, 169, 2665-2683. [CrossRef] [PubMed]

237. Glaubitz, U.; Li, X.; Schaedel, S.; Erban, A.; Sulpice, R.; Kopka, J.; Hincha, D.K.; Zuther, E. Integrated analysis of rice transcriptomic and metabolomic responses to elevated night temperatures identifies sensitivity- and tolerance-related profiles. Plant Cell Environ. 2017, 40, 121-137. [CrossRef]

238. Liu, Z.; Xin, M.; Qin, J.; Peng, H.; Ni, Z.; Yao, Y.; Sun, Q. Temporal transcriptome profiling reveals expression partitioning of homeologous genes contributing to heat and drought acclimation in wheat (Triticum aestivum L.). BMC Plant Biol. 2015, 15, 152. [CrossRef] 
239. Vriet, C.; Hennig, L.; Laloi, C. Stress-induced chromatin changes in plants: Of memories, metabolites and crop improvement. Cell. Mol. Life Sci. 2015, 72, 1261-1273. [CrossRef]

240. Sanyal, R.P.; Misra, H.S.; Saini, A. Heat-stress priming and alternative splicing-linked memory. J. Exp. Bot. 2018, 69, $2431-2434$. [CrossRef]

241. Sani, E.; Herzyk, P.; Perrella, G.; Colot, V.; Amtmann, A. Hyperosmotic priming of Arabidopsis seedlings establishes a long-term somatic memory accompanied by specific changes of the epigenome. Genome Biol. 2013, 14, 1-24. [CrossRef]

242. Mauch-Mani, B.; Baccelli, I.; Luna, E.; Flors, V. Defense priming: An adaptive part of induced resistance. Annu. Rev. Plant Biol. 2017, 68, 485-512. [CrossRef]

243. Bäurle, I. Plant heat adaptation: Priming in response to heat stress. F1000 Res. 2016, 5, F1000 Faculty Rev-694. [CrossRef]

244. Berry, S.; Dean, C. Environmental perception and epigenetic memory: Mechanistic insight through FLC. Plant J. 2015, 83, 133-148. [CrossRef] [PubMed]

245. Ling, Y.; Serrano, N.; Gao, G.; Atia, M.; Mokhtar, M.; Woo, Y.H.; Bazin, J.; Veluchamy, A.; Benhamed, M.; Crespi, M.; et al. Thermo priming triggers splicing memory in Arabidopsis. J. Exp. Bot. 2018, 69, 2659-2675. [CrossRef]

246. Luco, R.F.; Allo, M.; Schor, I.E.; Kornblihtt, A.R.; Misteli, T. Epigenetics in alternative pre-mRNA splicing. Cell 2011, 144, 16-26. [CrossRef] [PubMed]

247. Kinoshita, T.; Seki, M. Epigenetic memory for stress response and adaptation in plants. Plant Cell Physiol. 2014, 55, 1859-1863. [CrossRef] [PubMed]

248. Bhardwaj, A.; Sita, K.; Sehgal, A.; Bhandari, K.; Kumar, S.; Prasad, P.V.V.; Jha, U.; Kumar, J.; Siddique, K.H.M.; Nayyar, H. Heat Priming of Lentil (Lens culinaris Medik.) seeds and foliar treatment with $\gamma$-aminobutyric acid (GABA), confers protection to reproductive function and yield traits under high-temperature stress environments. Int. J. Mol. Sci. 2021, 22, 5825. [CrossRef]

249. Ci, D.; Song, Y.; Tian, M.; Zhang, D. Methylation of miRNA genes in the response to temperature stress in Populus simonii. Front. Plant Sci. 2015, 6, 921. [CrossRef]

250. Biswas, M.S.; Mano, J.I. Lipid peroxide-derived short-chain carbonyls mediate $\mathrm{H}_{2} \mathrm{O}_{2}$-induced and NaCl-induced programmed cell death in plants. Plant Physiol. 2015, 168, 885-898. [CrossRef]

251. Jain, M.; Misra, G.; Patel, R.K.; Priya, P.; Jhanwar, S.; Khan, A.W.; Shah, N.; Singh, V.K.; Garg, R.; Jeena, G.; et al. A draft genome sequence of the pulse crop chickpea (Cicer arietinum L.). Plant J. 2013, 74, 715-729. [CrossRef]

252. Pellicer, J.; Hidalgo, O.; Dodsworth, S.; Leitch, I. Genome size diversity and its impact on the evolution of land plants. Genes 2018, 9, 88. [CrossRef]

253. Emmrich, P.M.; Sarkar, A.; Njaci, I.; Kaithakottil, G.G.; Ellis, N.; Moore, C.; Edwards, A.; Heavens, D.; Waite, D.; Cheema, J.; et al. A draft genome of grass pea (Lathyrus sativus), a resilient diploid legume. bioRxiv 2020. [CrossRef]

254. Sudheesh, S.; Verma, P.; Forster, J.W.; Cogan, N.O.; Kaur, S. Generation and characterisation of a reference transcriptome for lentil (Lens culinaris Medik.). Int. J. Mol. Sci. 2016, 17, 1887. [CrossRef]

255. Schmutz, J.; McClean, P.E.; Mamidi, S.; Wu, G.A.; Cannon, S.B.; Grimwood, J.; Jenkins, J.; Shu, S.; Song, Q.; Chavarro, C.; et al. A reference genome for common bean and genome-wide analysis of dual domestications. Nat. Genet. 2014, 46, 707-713. [CrossRef]

256. Kang, Y.J.; Satyawan, D.; Shim, S.; Lee, T.; Lee, J.; Hwang, W.J.; Kim, S.K.; Lestari, P.; Laosatit, K.; Kim, K.H.; et al. Draft genome sequence of adzuki bean, Vigna angularis. Sci. Rep. 2015, 5, 8069. [CrossRef] [PubMed]

257. Sivasakthi, K.; Thudi, M.; Tharanya, M.; Kale, S.M.; Kholová, J.; Halime, M.H.; Jaganathan, D.; Baddam, R.; Thirunalasundari, T.; Gaur, P.M.; et al. Plant vigour QTLs co-map with an earlier reported QTL hotspot for drought tolerance while water saving QTLs map in other regions of the chickpea genome. BMC Plant Biol. 2018, 18, 29. [CrossRef] [PubMed]

258. Ricroch, A.; Clairand, P.; Harwood, W. Use of CRISPR systems in plant genome editing: Toward new opportunities in agriculture. Emerg. Top. Life Sci. 2017, 1, 169-182. [PubMed]

259. Zaidi, S.S.; Mukhtar, M.S.; Mansoor, S. Genome editing: Targeting susceptibility genes for plant disease resistance. Trends Biotechnol. 2018, 36, 898-906. [CrossRef]

260. Guichard, A.; Haque, T.; Bobik, M.; Xu, X.R.; Klanseck, C.; Kushwah, R.B.; Berni, M.; Kaduskar, B.; Gantz, V.M.; Bier, E. Efficient allelic-drive in Drosophila. Nat. Commun. 2019, 10, 1640. [CrossRef]

261. Li, M.; Li, X.; Zhou, Z.; Wu, P.; Fang, M.; Pan, X.; Lin, Q.; Luo, W.; Wu, G.; Li, H. Reassessment of the four yield-related genes Gn1a, DEP1, GS3, and IPA1 in rice using a CRISPR/Cas9 system. Front. Plant Sci. 2016, 7, 377. [CrossRef]

262. Shi, J.; Gao, H.; Wang, H.; Lafitte, H.R.; Archibald, R.L.; Yang, M.; Hakimi, S.M.; Mo, H.; Habben, J.E. ARGOS 8 variants generated by CRISPR-Cas9 improve maize grain yield under field drought stress conditions. Plant Biotechnol. J. 2017, 15, 207-216. [CrossRef]

263. Kim, D.; Alptekin, B.; Budak, H. CRISPR/Cas9 genome editing in wheat. Funct. Integr. Genom. 2018, 18, 31-41. [CrossRef]

264. Janni, M.; Gullì, M.; Maestri, E.; Marmiroli, M.; Valliyodan, B.; Nguyen, H.T.; Marmiroli, N. Molecular and genetic bases of heat stress responses in crop plants and breeding for increased resilience and productivity. J. Exp. Bot. 2020, 71, 3780-3802. [CrossRef] [PubMed]

265. Badhan, S.; Ball, A.S.; Mantri, N. First Report of CRISPR/Cas9 mediated DNA-free editing of $4 C L$ and RVE7 genes in chickpea protoplasts. Int. J. Mol. Sci. 2021, 22, 396. [CrossRef] [PubMed]

266. Bhowmik, P.; Konkin, D.; Polowick, P.; Hodgins, C.L.; Subedi, M.; Xiang, D.; Yu, B.; Patterson, N.; Rajagopalan, N.; Babic, V.; et al CRISPR/Cas9 gene editing in legume crops: Opportunities and challenges. Legume Sci. 2021. [CrossRef]

267. Uauy, C. Wheat genomics comes of age. Curr. Opin. Plant Biol. 2017, 36, 142-148. [CrossRef] [PubMed]

268. Wang, T.; Uauy, C.; Till, B.; Liu, C.M. TILLING and associated technologies. J. Integr. Plant Biol. 2010, 52, 1027-1030. [CrossRef] 
269. Comastri, A.; Janni, M.; Simmonds, J.; Uauy, C.; Pignone, D.; Nguyen, H.T.; Marmiroli, N. Heat in wheat: Exploit reverse genetic techniques to discover new alleles within the Triticum durum sHsp26 family. Front. Plant Sci. 2018, 9, 1337. [CrossRef]

270. Marko, D.; El-Shershaby, A.; Carriero, F.; Summerer, S.; Petrozza, A.; Iannacone, R.; Schleiff, E.; Fragkostefanakis, S. Identification and characterization of a thermos tolerant TILLING allele of heat shock binding protein 1 in tomato. Genes 2019, $10,516$. [CrossRef]

271. Porch, T.G. Application of stress indices for heat tolerance screening of common bean. J. Agron. Crop Sci. 2006, 192, 390-394. [CrossRef]

272. Xu, C.; Huang, B. Root proteomic responses to heat stress in two Agrostis grass species contrasting in heat tolerance. J. Exp. Bot. 2008, 59, 4183-4194. [CrossRef]

273. Liu, X.; Huang, B. Root physiological factors involved in cool-season grass response to high soil temperature. Environ. Exp. Bot. 2005, 53, 233-245. [CrossRef]

274. Valdés-López, O.; Batek, J.; Gomez-Hernandez, N.; Nguyen, C.T.; Isidra-Arellano, M.C.; Zhang, N.; Joshi, T.; Xu, D.; Hixson, K.K.; Weitz, K.K.; et al. Soybean roots grown under heat stress show global changes in their transcriptional and proteomic profiles. Front. Plant Sci. 2016, 7, 517. [CrossRef] [PubMed]

275. Chen, M.; von Mikecz, A. Formation on nucleoplasmic protein aggregates impairs nuclear function in response to $\mathrm{SiO}_{2}$ nanoparticles. Exp. Cell Res. 2005, 305, 51-62. [CrossRef] [PubMed]

276. Buzea, C.; Pacheco, B.I.; Robbie, K. Nanomaterials and nanoparticles: Sources and toxicity. Biointerphases 2007, 2, 17-72. [CrossRef]

277. Rico, C.M.; Duarte, S.; Garden, M.; Peralta-Videa, J.R.; Gardea-Torrcsdcy, J.L. Interaction of nanoparticles with edible plants and their possible implications in the food chain. J. Agric. Food Chem. 2011, 59, 3485-3498. [CrossRef]

278. Hofmann, T.; Lowry, G.V.; Ghoshal, S.; Tufenkji, N.; Brambilla, D.; Dutcher, J.R.; Gilbertson, L.M.; Giraldo, J.P.; Kinsella, J.M.; Landry, M.P.; et al. Technology readiness and overcoming barriers to sustainably implement nanotechnology-enabled plant agriculture. Nat. Food 2020, 1, 416-425. [CrossRef]

279. Al-Ahmadi, M.S. Cytogenetic and molecular assessment of some nanoparticles using Allium sativum assay. Afr. J. Biotechnol. 2019, 18, 783-796.

280. Jha, S.; Pudake, R.N. Molecular mechanism of plant-nanoparticle interactions. In Plant Nanotechnology; Kole, C., Kumar, D., Khodakovskaya, M., Eds.; Springer Publishing: Cham, Switzerland, 2016; pp. 155-181. 